\title{
GINO ARRUNÁTEGUI
}

\section{Enxertos combinados de derme alógena residual, preservada em glicerol, sobreposta por pele autógena, como cobertura definitiva de queimaduras profundas - relato de casos}

Dissertação apresentada à Faculdade de Medicina da Universidade de São Paulo para obtenção do título de Mestre em Ciências

Área de concentração: Cirurgia Plástica Orientadora: Dra. Marisa Roma Herson

SÃO PAULO 2006 


\section{Dados Internacionais de Catalogação na Publicação (CIP)}

Preparada pela Biblioteca da

Faculdade de Medicina da Universidade de São Paulo

Creprodução autorizada pelo autor

\section{Arrunátegui, Gino}

Enxertos combinados de derme alógena residual, preservada em glicerol, sobreposta por pele autógena, como cobertura definitiva de queimaduras profundas : relato de casos / Gino Arrunátegui. -- São Paulo, 2006.

Dissertação(mestrado)--Faculdade de Medicina da Universidade de São Paulo. Departamento de Cirurgia.

Área de concentração: Cirurgia Plástica.

Orientadora: Marisa Roma Herson.

Descritores: 1.Derme/transplante 2.Transplante homólogo 3.Queimaduras/cirurgia 4.Glicerol

USP/FM/SBD-427/06 


\section{DEDICATÓRIA}

A meus pais, a Gisele e a Gabriel 


\section{AGRADECIMENTOS}

Ao Prof. Dr. Marcus Castro Ferreira, pelos ensinamentos em minha formação como cirurgião plástico.

À Dra. Marisa Roma Herson, pela convivência sempre enriquecedora.

Ao Dr. Paulo Tuma Jr., pelo apoio e amizade.

Ao Dr. Paulo Cezar Cavalcante de Almeida, pelo apoio e amizade.

Aos Drs. Alexandre Wada, Wilson Cintra Jr e Márcio Paulino Costa, pelo apoio e incentivo, sempre.

Aos pacientes, doadores e receptores.

A todos os profissionais da Unidade de Tratamento de Queimaduras do HCFMUSP e do Banco de Tecidos do ICHCFMUSP, sem os quais este trabalho não teria sido possível. 


\section{EPÍGRAFE}

“Nada é tão forte quanto uma idéia cujo tempo chegou..."

\section{Victor Hugo}

"God, give us grace to accept with serenity the things that cannot be changed, courage to change the things that should be changed, and the wisdom to distinguish the one from the other"

Reinhold Niebuhr 


\section{NORMATIZAÇÃO ADOTADA}

Esta dissertação está de acordo com as seguintes normas, em vigor no momento desta publicação:

Referências: adaptado de International Committee of Medical Journals Editors (Vancouver)

Universidade de São Paulo. Faculdade de Medicina. Serviço de Biblioteca e Documentação. Guia de apresentação de dissertações, teses e monografias. Elaborado por Anneliese Carneiro da Cunha, Maria Julia de A. L. Freddi, Maria F. Crestana, Marinalva de Souza Aragão, Suely Campos Cardoso, Valéria Vilhena. $2^{a}$ ed. São Paulo: Serviço de Biblioteca e Documentação; 2005.

Abreviaturas dos títulos dos periódicos de acordo com List of Journals Indexed in Index Medicus. 


\section{SUMÁRIO}

Lista de abreviaturas

Lista de símbolos

Lista de figuras

Lista de tabelas

Resumo

Summary

1. INTRODUÇÃO

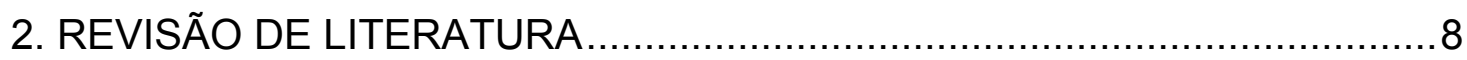

2.1 Aplicação clínica de enxertos de pele alógenos - referencial teórico ..9 2.1.1 Preservação de pele ..................................................10

2.1.1.1 Os métodos de resfriamento ................................11

2.1.1.2 O método de glicerolização...................................13



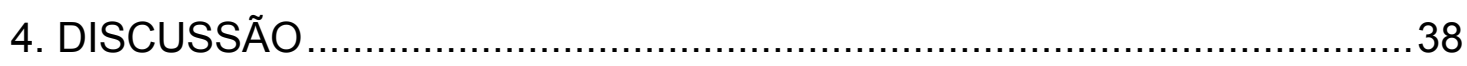

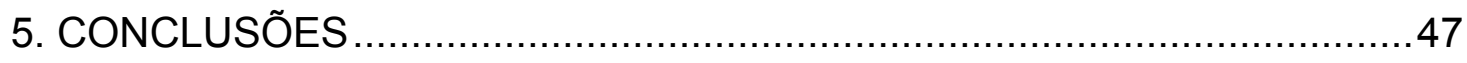

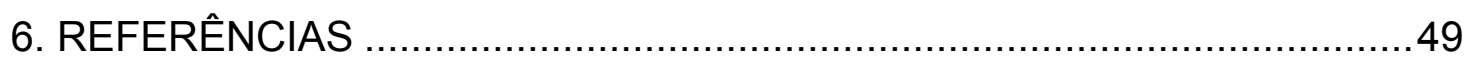




\section{LISTA DE ABREVIATURAS}

$\begin{array}{ll}\text { alo-EPEP(s) } & \text { enxerto(s) de pele de espessura parcial alógeno(s) } \\ \text { auto-EPEP(s) } & \text { enxerto(s) de pele de espessura parcial autógeno(s) } \\ \text { dpq(s) } & \text { dia(s) pós-queimadura } \\ \text { et al. } & \text { e outros } \\ \text { EACP(s) } & \text { enxerto(s) alógeno(s) criopreservado(s) } \\ \text { EAPG(s) } & \text { enxerto(s) alógeno(s) preservado(s) em glicerol } \\ \text { EPEP(s) } & \text { enxerto(s) de pele de espessura parcial } \\ \text { EUA. } & \text { Estados Unidos da América } \\ \text { f. } & \text { feminino } \\ \text { m. } & \text { masculino } \\ \text { n. } & \text { número } \\ \text { p. } & \text { página } \\ \text { scq } & \text { superfície corporal queimada } \\ \text { Prof. } & \text { Professor } \\ \text { USP. } & \text { Universidade de São Paulo } \\ \text { v. } & \text { nolume }\end{array}$




\section{LISTA DE SÍMBOLOS}

$\begin{array}{ll}\% & \text { porcentagem } \\ { }^{\circ} \mathrm{C} & \text { graus celsus } \\ \mathrm{cm} & \text { centímetro } \\ \mathrm{cm} 2 & \text { centímetro quadrado } \\ \mathrm{g} & \text { grama } \\ \mathrm{ml} & \text { mililitro } \\ \mathrm{mm} & \text { milímetro }\end{array}$




\section{LISTA DE FIGURAS}

FIGURA 1. a) Enxerto alógeno em lâmina ( $12^{\circ}$ dia após enxertia). b) Enxerto combinado ( $16^{\circ}$ dia de pós-operatório). c) Enxerto combinado (três meses de pós-operatório)

FIGURA 2. Enxerto alógeno em malha, já totalmente sem epiderme $\left(12^{\circ}\right.$ dia pós-enxertia).

FIGURA 3. Enxerto alógeno em malha, já totalmente sem epiderme, recoberto por enxerto autógeno em malha (pós-operatório imediato)

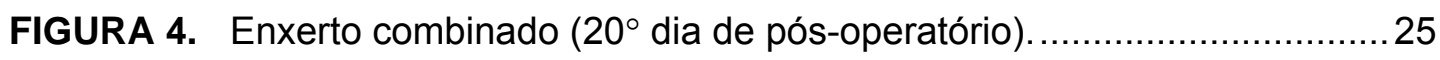

FIGURA 5. Enxerto combinado (2 meses de pós-operatório). ............................25

FIGURA 6. Enxerto combinado (46 meses de pós-operatório) .............................25

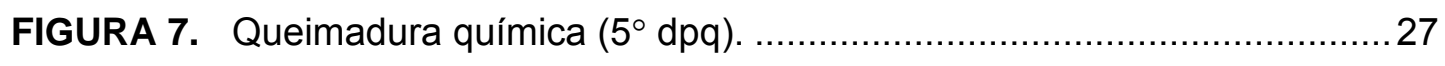

FIGURA 8. Acometimento da hipoderme, evidenciado após excisão tangencial

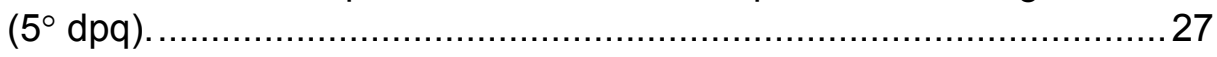

FIGURA 9. Ferida após desbridamento cirúrgico e preparo do leito com curativos diários com papaína $\left(12^{\circ} \mathrm{dpq}\right)$..........................................2 27

FIGURA 10. Enxertos alógenos em lâminas (pós-operatório imediato). ..................28

FIGURA 11. Enxertos alógenos em lâminas ainda com restos de epiderme $\left(9^{\circ}\right.$ dia de pós-operatório).

FIGURA 12. Enxertos alógenos em lâminas com a separação dermoepidérmica já completada ( $14^{\circ}$ dia de pós-operatório), prontos para receber os enxertos autógenos....

FIGURA 13. Enxertos combinados (pós-operatório imediato)............................... 29

FIGURA 14. Enxertos combinados ( $7^{\circ}$ dia de pós-operatório). ............................. 29

FIGURA 15. Enxertos combinados ( 6 meses de pós-operatório)........................... 29

FIGURA 16. Extensão completa do joelho (27 meses de pós-operatório). ..............30

FIGURA 17. Flexão completa do joelho (27 meses de pós-operatório). .................. 30

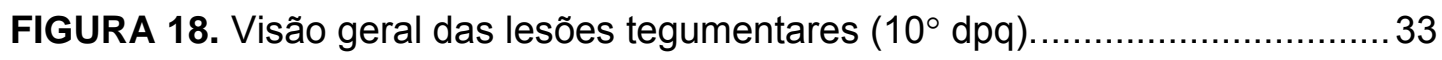

FIGURA 19. Necrose cutânea em área não-queimada $\left(10^{\circ} \mathrm{dpq}\right)$......................... 33

FIGURA 20. Necrosectomia realizada no plano epifascial $\left(10^{\circ} \mathrm{dpq}\right)$.....................33 
FIGURA 21. Visão geral das áreas cruentas após o primeiro desbridamento $\left(11^{\circ} \mathrm{dpq}\right)$.

FIGURA 22. Preparo do leito da ferida com curativos de carvão ativado $\left(24^{\circ} \mathrm{dpq}\right)$.

FIGURA 23. Aspecto do leito da ferida no dia da enxertia alógena definitiva $\left(26^{\circ} \mathrm{dpq}\right)$.

FIGURA 24. Enxertos alógenos em malha 1:3, com a separação dermoepidérmica em progressão ( $6^{\circ}$ dia de pós-operatório).

FIGURA 25. Aspecto dos enxertos alógenos ( $20^{\circ}$ dia de pós-operatório) no dia da enxertia autógena.

FIGURA 26. Enxertia combinada (pós-operatório imediato). 35

FIGURA 27. Visão geral do tegumento resultante do tratamento $\left(26^{\circ}\right.$ dia de pós-operatório).

FIGURA 28. Enxertos combinados em dorso ( $26^{\circ}$ dia de pós-operatório). 36

FIGURA 29. Enxertos combinados em dorso ( $48^{\circ}$ dia de pós-operatório). 36 


\section{LISTA DE TABELAS}

TABELA 1 - Resumo dos casos relatados ................................... 37 


\section{RESUMO}

Arrunátegui G. Enxertos combinados de derme alógena residual, preservada em glicerol, sobreposta por pele autógena, como cobertura definitiva de queimaduras profundas: relato de casos [dissertação]. São Paulo: Faculdade de Medicina, Universidade de São Paulo; 2006. 60p.

Ainda que resulte na sobrevida do paciente, o tratamento atual de queimaduras profundas e extensas é imperfeito. A contratura cicatricial e o aspecto rendilhado persistentes na área enxertada produzem resultados estéticos e funcionais pobres. A principal dificuldade no adequado restabelecimento do tegumento destes pacientes é o déficit de derme, decorrente da reposição das perdas com enxertos relativamente finos. Neste trabalho são relatados quatro casos, decorrentes da familiaridade obtida em nossa prática clínica com o emprego de pele preservada em glicerol, nos quais foi utilizada a enxertia combinada, isto é, derme alógena residual sobreposta por enxertos de espessura parcial autógenos, como forma de reposição de matriz dérmica. Os tegumentos resultantes da enxertia combinada mostraram-se estáveis e duráveis, dentro do período de seguimento dos casos apresentados.

Descritores: matriz dérmica - enxerto de pele alógeno preservado em glicerol - enxerto de pele - queimaduras/cirurgia 


\section{SUMMARY}

Arrunátegui G. Combined grafts of glycerol preserved residual allogeneous dermis put upon by autogenous skin as definitive covering of deep burns: cases report [Dissertation]. São Paulo: "Faculdade de Medicina, Universidade de São Paulo"; 2006. 60p.

Although it results in the patient's survival, the current treatment of deep and extensive burns is imperfect. Scar contracture and the persistent lacy aspect in the grafted area produce aesthetic and functional poor results. The main difficulty in the appropriate re-establishment of the tegument of these patients is the deficit of dermis, due to the replacement of the skin losses with relatively thin grafts. In this work, decurrent of the familiarity obtained in our clinical practice with glycerol preserved cadaver skin, four cases are reported, which the combined grafting was used, that is, residual allogeneous dermis put upon by split thickness autogenous grafts, as form of replacement of dermal matrix. The resulting teguments of the combined grafting were shown stable and durable, inside the follow-up period of the presented cases.

Descriptors: dermal matrix - glycerol preserved skin allograft - skin graft burns/surgery 
Perdas cutâneas significativas, como ocorre em pacientes com queimaduras extensas e profundas (isto é, lesões de espessura parcial profunda e de espessura total), são associadas a altas taxas de morbimortalidade devido à perda de fluidos, proteínas, eletrólitos e à suscetibilidade à sépsis. Perdas cutâneas moderadas também podem apresentar morbidade considerável e impacto negativo na qualidade de vida.

No momento atual, o melhor tratamento para as queimaduras descritas acima é a obtenção do fechamento definitivo das feridas o mais rapidamente possível com enxerto de pele de espessura parcial autógeno (auto-EPEP) ${ }^{1}$. Artifícios para melhor aproveitamento de áreas doadoras (que costumam ser escassas) auxiliam neste intento. Estes incluem técnicas de enxertia em malha e retiradas de enxertos de espessura parcial mais finos, de um mesmo local mais repetidas vezes.

Mesmo assim, em pacientes com lesões que envolvem mais que cinqüenta porcento da superfície corporal, torna-se impossível cobrir de imediato toda a área cruenta. Nestes casos, a cobertura temporária com pele doada por outra pessoa (enxerto alógeno ou homógeno) é essencial ${ }^{2}$. Com este expediente, é possível obter-se a redução dos fenômenos fisiopatológicos associados à perda cutânea através do fechamento 
provisório da ferida, até que seja possível a cobertura definitiva com enxertia de pele autógena.

Contudo, ainda que possa resultar na sobrevida do paciente, a reposição de perdas cutâneas de maior espessura com tais métodos é imperfeita. A retirada de enxertos cria uma lesão de espessura parcial na área doadora; esta é novamente epitelizada a partir dos anexos epidérmicos remanescentes no leito da ferida. Entretanto, como a derme não se regenera, é possível a retirada de apenas algumas porções de derme de cada vez (na forma de enxerto), e por duas a três vezes no mesmo local. Enxertos de pele de espessura parcial (EPEPs) em malha aumentam a quantidade de cobertura disponível. Porém, as áreas vazadas da malha do enxerto não contêm nenhum elemento dérmico, e são reparadas por cicatrização secundária. A contratura cicatricial e o aspecto rendilhado persistentes na área enxertada produzem resultados estéticos e funcionais pobres.

A principal dificuldade no adequado restabelecimento do tegumento de pacientes com queimaduras profundas é a perda de derme. KLEIN e RUDOLPH ${ }^{3}$, em 1972, demonstraram que a formação de contratura cicatricial na área enxertada é inversamente proporcional à espessura da derme transplantada. Por outro lado, na medida em que se aumenta a espessura da derme retirada na forma de enxerto, ou que se aumenta o número de retiradas numa mesma área doadora, observa-se o aumento da morbidade associada ao procedimento ${ }^{1}$ : maior incidência de dor, infecção, atrasos na epitelização e formação de cicatriz hipertrófica na área doadora. 
Ainda, a contração secundária que sofre um enxerto é influenciada pela profundidade do leito da ferida, sendo maior quando o enxerto é colocado sobre a fáscia que quando colocado sobre a hipoderme ${ }^{4}$ A conseqüência, portanto, do tratamento de queimaduras profundas e extensas é um déficit de derme, decorrente da reposição das perdas com enxertos relativamente finos.

Os resultados observados com a aplicação de enxertos epidérmicos autógenos cultivados (isto é, obtidos através de cultura de células epiteliais a partir de uma pequena amostra de pele) no tratamento de pacientes queimados ${ }^{5,6}$ reforçaram a importância da necessidade da recomposição da derme para que se tenha a reconstituição funcional do tegumento ${ }^{7}$. Foi observado que as feridas fechadas somente com componentes epidérmicos eram frágeis e instáveis, com a formação de bolhas, ulcerações recorrentes e contraturas cicatriciais em longo prazo ${ }^{8}$.

A debilidade das feridas fechadas com queratinócitos cultivados motivou a tentativa de utilização destas células em combinação com um substrato dérmico. CUONO et al. ${ }^{9,10}$ e LANGDON et al. ${ }^{11}$ descreveram técnica na qual queratinócitos cultivados foram enxertados em feridas previamente cobertas com enxerto de pele de espessura parcial alógeno (alo-EPEP) criopreservado. Os enxertos alógenos mantidos no leito da ferida foram integrados e, após três semanas, tiveram suas células epiteliais removidas por dermabrasão ou excisão tangencial, deixando para trás um leito dérmico vascularizado. 
Embora o emprego rotineiro do conceito seja mais recente, a observação da sobrevivência persistente de resíduos de derme integrados ao leito da ferida, oriundos de enxertos alógenos aplicados a princípio como cobertura temporária foi relatada por GIBSON ${ }^{12,}$ em 1943 . Este caso, uma menina de dois anos cujas queimaduras foram cobertas com enxertos alógenos doados por seu pai, tornou-se célebre por ter estimulado MEDAWAR a se juntar a GIBSON no Glasgow Royal Infirmary Research Unity, um passo importante nos estudos que levaram o primeiro a receber o Prêmio Nobel em 1960.

MEDAWAR ${ }^{13}$, em seguida, registrou que a derme alógena persistente era destituída de sua própria epiderme e logo coberta pela migração do epitélio do receptor e conjecturou que o componente dérmico era menos imunorreativo que o componente epidérmico. JACKSON ${ }^{14}$ explorou esses fenômenos na década de 1950 com seus enxertos em "listras de zebra", que consistiam de listras de enxertos alógenos intercalados com listras de enxertos autógenos; a epiderme autógena era coalescida na medida em que a epiderme alógena era perdida.

O conceito do uso de derme alógena propositalmente como substrato definitivo para enxertia de epiderme autógena foi relatado tanto experimental quanto clinicamente pela primeira vez por HECK et al. ${ }^{15}$. Feridas de espessura total de pequeno diâmetro foram cobertas com alo-EPEP criopreservado. Três a cinco dias depois, o que foi descrita como "epiderme morta" foi destacada da derme, que permaneceu aderida ao leito da ferida. Enxertos epidérmicos de $5 \mathrm{~mm}$ de diâmetro (retirados da porção superior de bolhas criadas por sucção) foram então colocados sobre a superfície 
dérmica. Os autores observaram epitelização completa e progressiva ao longo de vários dias e ausência de contração secundária do enxerto em dez meses de seguimento. HECK et al. ${ }^{15}$ demonstraram que enxertos combinados de derme alógena e epiderme autógena podem ser aplicados com sucesso em receptores imunocompetentes, originando uma cobertura estável em longo prazo; os autores supuseram que a derme alógena residual criopreservada era pouco ou nada imunogênica.

Foi relatado que enxertos alógenos preservados em glicerol também funcionam satisfatoriamente como leito dérmico para enxertos de queratinócitos cultivados ${ }^{16,17,18}$. Em nosso meio, HERSON et al. ${ }^{19}$ demonstraram, em estudo in vitro, que uma preparação especial de derme acelular preservada em glicerol podia ser usada como substrato para a proliferação de queratinócitos humanos, e que as características deste tecido obtido por bioengenharia sugeriam seu possível uso como um substituto cutâneo permanente.

A familiaridade obtida em nossa prática clínica com o emprego da pele preservada em glicerol levou-nos a utilizá-la também na forma de enxertos combinados, isto é, derme alógena residual sobreposta por enxertos de espessura parcial autógenos. Nos casos em que foi empregada, tal enxertia pareceu suprir, em grau considerável, o tal "déficit de derme". A partir destas observações, fomos estimulados a versar sobre os benefícios do uso de enxertos alógenos preservados em glicerol, não só por atuarem como substituto cutâneo em queimaduras extensas, mas também por contribuírem com a reposição das perdas de matriz dérmica. 
Este trabalho descreve o atendimento prestado a quatro pacientes na Unidade de Tratamento de Queimaduras (UTQ) da Divisão de Cirurgia Plástica e Queimaduras do Hospital das Clínicas da Faculdade de Medicina da Universidade de São Paulo (HCFMUSP), no período de julho de 2002 a março de 2005, nos quais foi realizado o procedimento de enxertia combinada. Esta conduta incorpora conceitos e técnicas conhecidas; porém, não haviam sido relatados, previamente, casos clínicos nos quais foram empregados alo e auto-enxertos de pele da maneira aqui demonstrada. 


\subsection{APLICAÇÃO CLÍNICA DE ENXERTOS DE PELE ALÓGENOS - REFERENCIAL TEÓRICO}

O início dos relatos científicos sobre a utilização de enxertos de pele deu-se na Europa no século XIX. Em 1804, BARONIO executou as primeiras experiências bem documentadas de enxertia autógena de pele em um modelo ovino ${ }^{20}$. Em 1869, REVERDIN ${ }^{21}$, trabalhando em Paris, tratou um caso de avulsão com enxerto autógeno e relatou o uso de enxertos alógenos de pele no ano seguinte ${ }^{22}$. Em 1870, LAWSON ${ }^{23}$, um oftalmologista, usou enxertos autógenos de espessura total na reconstrução de pálpebras na Grã-Bretanha. POLLOCK ${ }^{24}$ foi o primeiro a relatar o uso de enxertos de pele no tratamento de queimaduras, em 1871.

GIRDNER ${ }^{25}$, nos Estados Unidos, relatou pela primeira vez o uso clínico de enxerto alógeno de doador cadáver para tratamento de um paciente com queimadura extensa em 1881. De 1882 são os primeiros relatos de efeitos adversos do transplante de pele alógena, quando quatro pacientes tiveram varíola após receberem enxertos de uma pessoa que teve o braço amputado e era portadora da doença ${ }^{26}$.

A pele alógena era considerada uma cobertura permanente, até que LEXER, em 1914, descreveu certa "incompatibilidade" a tal material ${ }^{26}$. Em 
1932, PADGETT relatou perda completa da pele de cadáver após o $35^{\circ}$ dia de transplante em quarenta pacientes, confirmando a teoria de LEXER ${ }^{2}$. Desde então, o uso de pele alógena como cobertura apenas temporária (pelo período que antecede a rejeição) tornou-se convencional ${ }^{26}$.

\subsubsection{Preservação de pele}

Os estudos para preservação de pele surgiram da necessidade de acúmulo e estocagem do material para sua aplicação a posteriori, em momentos de maior necessidade. A utilização de pele preservada teria outras vantagens: poderia ser extensivamente testada para a presença de transmissores de doenças e o processo de preservação, em si, poderia eliminar certos patógenos.

O desenvolvimento do US Navy Skin Bank em Bethesda, Maryland, em 1949, é considerado o marco inicial dos tempos modernos da preservação de pele em bancos especializados ${ }^{27}$. O uso rotineiro de enxerto

de pele alógena não ocorreu até os anos de 1950, quando BROWN et al. ${ }^{28}$ relataram sua utilidade como curativo biológico em pacientes com queimaduras.

O avanço das pesquisas nos últimos quarenta anos resultou em melhoria dos métodos de preservação e tornou possível o fornecimento de cobertura cutânea suficiente e prontamente acessível ao paciente com queimaduras extensas pelos "laboratórios" que ficaram conhecidos como bancos de pele. Com o aumento da demanda pelos enxertos alógenos 
preservados, a responsabilidade pela captação, armazenamento e distribuição foi transferida das pequenas organizações locais iniciais para instituições de cunho regional ou nacional ${ }^{29}$.

Os maiores centros de pesquisas têm enfocado o tema da preservação sob ângulos diferentes. De maneira geral, os estudiosos norte-americanos têm valorizado a manutenção da viabilidade dos tecidos, através da utilização de métodos que envolvem, principalmente, o resfriamento dos enxertos. Enxertos viáveis contêm células que possuem atividade metabólica; as células dos enxertos não-viáveis não apresentam qualquer atividade.

Já na Holanda e em outros países da Europa Ocidental ganhou popularidade a teoria de que a manutenção da viabilidade da pele não seria necessária para a obtenção dos efeitos desejados com os transplantes ${ }^{30,} 31$. Embora tenha iniciado suas atividades oito anos antes utilizando a criopreservação, a partir de 1984 o banco de pele da Fundação Holandesa de Queimaduras (que depois viria a se tornar o Euro Skin Bank, sediado na cidade holandesa de Beverwijk) passou utilizar a glicerolização, isto é, o processamento dos enxertos em concentrações progressivamente maiores de glicerol ${ }^{32}$. Este método de preservação produz material menos imunogênico, não-viável, porém de desempenho plenamente suficiente ${ }^{31}$.

\subsubsection{Os métodos de resfriamento}

Atualmente, os métodos de preservação que mantêm a viabilidade dos enxertos, segundo a normatização da European Association of Tissue Banks $^{33}$, incluem refrigeração da pele fresca a temperaturas de 1 a $10^{\circ}$. C, 
em soro fisiológico ou em meios de conservação específicos, e a congelação ou criopreservação a temperaturas abaixo de $-40^{\circ} \mathrm{C}$.

CARREL ${ }^{34}$, por suas publicações no início do século $X X$, é considerado o precursor do emprego da refrigeração como método de armazenamento de tecidos humanos. No entanto, somente em 1944, MATTHEWS ${ }^{35}$ deu a primeira descrição completa do armazenamento de pele autógena sob refrigeração e seu emprego clínico. Tal técnica de estocagem, em refrigerador comum a $4^{\circ} \mathrm{C}$, ampliou as possibilidades de aplicação do material, até então de provisão obviamente limitada. No entanto, foi observado que os enxertos frescos refrigerados deterioravam-se progressivamente e tornavam-se inadequados para o uso após catorze dias ${ }^{36}$. Tais fatos demonstraram a necessidade de um sistema que conservasse os tecidos por mais tempo ${ }^{37}$.

COCHRANE ${ }^{38}$, em 1966, informou o primeiro uso clínico de enxerto (autógeno) processado através do método de criopreservação. Nesta técnica, os enxertos colhidos são mergulhados em soluções crioprotetoras a base de dimetilsulfoxide ou glicerol a $15 \%$ e submetidos a um processo de congelamento progressivo controlado, de 0,5 a $5{ }^{\circ} \mathrm{C}$ por minuto ${ }^{39}$. As soluções crioprotetoras são capazes de controlar a formação de cristais de gelo nos tecidos durante a congelação e, com isso, reduzir a lesão celular associada ao processo. Foi demonstrado que a criopreservação é capaz de proteger a estrutura dos tecidos, não danificar componentes vitais e manter o nível de metabolismo nos enxertos igual a aproximadamente $80 \%$ daquele presente nos enxertos frescos (isto é, não submetidos a nenhum tipo de processamento) ${ }^{40}$. 
Uma vez criopreservada, a pele pode ser armazenada por períodos variáveis: para cada temperatura de ambiente há uma combinação de tempo máximo de armazenamento, que deve ser monitorado continuamente; este não deve ser excedido, para que os enxertos possam ser usados com sucesso ${ }^{41}$. Para armazenamento em longo prazo, é preferível a manutenção do material imerso em nitrogênio líquido a temperaturas abaixo de $-130{ }^{\circ} \mathrm{C}{ }^{41}$. Antes de serem transplantados, é necessário que os enxertos sejam previamente submetidos à descongelação rápida.

Estudos demonstraram que a pele criopreservada por até seis meses (seja autógena ou alógena) pôde ser revascularizada a partir do leito e desempenhar sua função ${ }^{42,43,44}$. É relatado que o componente epidérmico do enxerto alógeno criopreservado (EACP) separa-se espontaneamente e destaca-se do restante (que fica aderido ao leito) após a primeira semana da enxertia ${ }^{45}$. Ainda que o processo de criopreservação tenha se mostrado capaz de atenuar as propriedades antigênicas dos alo-EPEPs ${ }^{42}$, foi observado que seus elementos epiteliais residuais sofrem rejeição três a quatro semanas depois de sua aplicação ${ }^{46}$.

\subsubsection{O método de glicerolização}

As alternativas de métodos de preservação de pele não-viável incluem a liofilização e a glicerolização; destes, esta última tem tido seu uso progressivamente aumentado nos tempos atuais.

O glicerol foi descrito como substância conservante eficaz de vários tecidos, incluindo cartilagem, córnea e vasos ${ }^{47}$. Em nosso meio, PIGOSSI ${ }^{48}$ 
realizou estudos pioneiros sobre as propriedades conservantes do glicerol. BASILE ${ }^{49}$, em 1982, inspirado pelos bons resultados descritos por Pigossi em dura-máter humana, estudou as propriedades da pele porcina glicerolizada e relatou sua utilização como curativo biológico em queimaduras de espessura total.

Em 1984, o banco de pele da Fundação Holandesa de Queimaduras desenvolveu método próprio de preservação de pele humana de doador cadáver em glicerol ${ }^{32}$. Desde então, a experiência acumulada em mais de uma década com a técnica em vários centros na Europa demonstrou que sua aplicação clínica é bastante satisfatória ${ }^{30,31}$.

Segundo BLOME-EBERWEIN et al. ${ }^{26}$, a glicerolização apresenta vantagens em relação à criopreservação porque é mais simples e apresenta melhor relação custo-benefício. A criopreservação envolve um processo de congelamento controlado que requer um equipamento especial, caro e sofisticado, normalmente não disponível em qualquer unidade de cirurgia plástica e queimaduras. Já a preservação em glicerol não requer nenhum equipamento especial. O custo de produção do enxerto alógeno preservado em glicerol (EAPG), segundo o Euro Skin Bank, varia de 60 a 90 centavos de dólar por $\mathrm{cm}^{2}$, o que é cinco a dez vezes menor que o custo de substitutos cutâneos temporários industrializados encontrados no mercado ${ }^{32}$. O armazenamento é feito à temperatura de $+4{ }^{\circ} \mathrm{C}$ em refrigeradores comuns, universalmente disponíveis. Nesta temperatura, o tempo de estocagem é de até dois anos.

Foi demonstrado, recentemente, que durante o processo de preservação o glicerol entra na pele e isola (e não substitui, como até então 
se supunha) a água componente do tecido ${ }^{50}$. A maioria dos mecanismos de deterioração que levam à perda dos tecidos armazenados requer a presença de água livre; assim sendo, com a glicerolização, as reações de degradação enzimática são inibidas ${ }^{50}$. A morfologia microscópica ${ }^{51}$, assim como a integridade estrutural do tecido são preservadas ${ }^{52}$. No entanto, as estruturas remanescentes não apresentam atividade metabólica, de forma que o EAPG deve ser considerado não-viável.

Foi demonstrado que o processo de glicerolização tem efeito antibacteriano ${ }^{32,47}$ e virucida ${ }^{53}$, com capacidade de inativar os vírus Herpes simples tipo I, poliovirus tipo I ${ }^{54}$ e HIV-1 ${ }^{55,56}$, quando em concentração de glicerol e à temperatura de incubação adequada. No entanto, não foi conclusivamente comprovada a destruição dos vírus da hepatite pelo método ${ }^{26}$.

A possibilidade de transmissão de agentes infecciosos via transplantação de células e tecidos é bem conhecida ${ }^{57,58}$. É relatado um único caso de transmissão de HIV a partir de doador soronegativo dentro da "janela imunológica”: o doador era múltiplo, e a transmissão só ocorreu nos receptores de órgãos frescos, mas não nos receptores de tecidos preservados ${ }^{59}$. Em outros casos relatados de transmissão do vírus HIV, isso se deu em situações onde não foi testada sorologia dos doadores, ou os órgãos e tecidos foram usados antes dos resultados de sorologia serem conhecidos ${ }^{59}$. Especificamente nesta última circunstância, é relatado um caso de transmissão de HIV através de enxerto alógeno de pele fresco, usado antes que os resultados sorológicos estivessem disponíveis ${ }^{57}$. 
É relatada a ocorrência de infecções por citomegalovírus (CMV) como consequência do uso de EACP provenientes de doadores cadáveres soropositivos para CMV em pacientes queimados soronegativos ${ }^{60}$. Tal possibilidade também foi demonstrada em experimento com murinos ${ }^{61}$. No entanto, as evidências sugerem que importância do potencial de transmissão de CMV para pacientes queimados através do uso de pele de cadáver preservada não é de magnitude significativa. A triagem para $\mathrm{CMV}$ é importante quando os receptores receberão drogas imunossupressoras após o transplante de órgão ${ }^{58}$. A imunossupressão que apresenta o paciente com queimaduras extensas não parece conduzir a problemas significativos relacionados ao $\mathrm{CMV}$, em receptores de enxerto alógeno de pele ${ }^{58}$. Estudos mostraram que, apesar de relativamente freqüente a comprovação sorológica de infecção de CMV durante a internação para tratamento de queimaduras, esta não contribuiu, diretamente ou indiretamente, para a morbidade ou mortalidade desses pacientes ${ }^{62,63}$. Segundo Herndon e Rose 64, os benefícios do uso de pele de cadáver em pacientes com queimaduras excedem claramente os riscos de transmissão de CMV. Não existem relatos de transmissão de CMV através de EAPG.

Embora a segurança definitiva quanto ao risco de infecção viral ainda seja objeto de discussão, a combinação do controle sorológico do doador com os demonstrados efeitos antivirais do glicerol reduzem o risco de contaminação acidental do receptor a níveis bem menores que aqueles observados com a transfusão sangüínea, dados os protocolos atuais de triagem de doadores e métodos de detecção viral ${ }^{32,57,59,65,66,67}$. Estudos 
que relatam a experiência clínica de centros na França ${ }^{68}$ e na Alemanha ${ }^{26}$ informam que não foi detectada a transmissão de doença infecciosa na população de pacientes tratados com EAPG.

Exatamente por ter suas estruturas vivas destruídas, argumenta-se que o EAPG teria sua imunogenicidade reduzida em comparação ao EACP 52, 69, 70 . A análise in vitro da imunogenicidade do EAPG mostrou que este suscita resposta inflamatória diminuída em comparação ao EACP ${ }^{70}$.

As indicações para o uso do EAPG têm sido as mesmas para o uso do EACP e podem ser agrupadas dentro de dois princípios diferentes. Primeiramente, o EAPG pode ser usado como cobertura cutânea temporária (isto é, o enxerto é vascularizado pelo leito, porém removido antes que ocorra a rejeição - geralmente após três semanas) ${ }^{46}$. Por exemplo, feridas resultantes de queimaduras extensas que foram excisadas podem ser cobertas temporariamente com EAPG até que o fechamento definitivo com pele autógena possa ser alcançado ${ }^{67,71}$.

A outra utilização do EAPG é como um curativo biológico, seja no tratamento de queimaduras de espessura parcial superficial ${ }^{30,72,73,74}$ em feridas com exposição de estruturas como vasos, nervos, tendão ou osso, em pacientes com necrólise epidérmica tóxica ${ }^{26}$, ou ainda, como cobertura de enxerto autógeno em malha muito expandido ${ }^{69}$. Nestes casos, o EAPG atua como um curativo colocado sobre a ferida, mantido no lugar pela adesividade à fibrina. Como não há contato vascular, não ocorre nenhuma reação imunogênica e o curativo se solta espontaneamente, à medida que a epitelização progride ${ }^{71,74}$. As vantagens deste uso são a imediata redução 
da dor com a aplicação do EAPG, prevenção de dessecação e aprofundamento da ferida, trocas de curativo mais fáceis e indolores e menor ocorrência de cicatrização hipertrófica ${ }^{30}$.

Ainda como curativo biológico, EAPG pode ser colocado e trocado sucessivamente em feridas já com tecido de granulação, mas de má qualidade, ou em pacientes numa condição geral pobre. Nestes casos, quando o EAPG se torna firmemente aderido à superfície de ferida, com sangramento no momento de sua remoção, é indicação que aconteceu adequado contato vascular entre o enxerto e o leito, e a ferida está pronta para receber um enxerto autógeno. Este procedimento é conhecido como o "teste da pega", e é feito com intuito de se reduzir a possibilidade de perda de um enxerto autógeno numa situação crítica ${ }^{67,71}$. 


\section{Caso 1}

Criança do sexo feminino, um ano e cinco meses de idade, parda, vítima de incêndio em residência, foi admitida com queimaduras de $2^{\circ}$ e $3^{\circ}$ graus envolvendo face, tronco anterior, braços, antebraços, mãos e membros inferiores, totalizando $38 \%$ da superfície corporal queimada (scq). No $16^{\circ}$ e $18^{\circ}$ dias pós-queimadura (dpqs), já com estabilização do quadro clínico geral, todas as áreas com queimaduras profundas foram excisadas no plano da hipoderme (gordura). Após hemostasia, o leito resultante foi imediatamente recoberto com EAPGs fornecidos pelo Banco de Tecidos do Instituto Central do Hospital das Clínicas da Faculdade de Medicina da Universidade de São Paulo (BT-IC-HCFMUSP), empregados a princípio como curativo biológico, isto é, substituídos em média a cada três ou sete dias. Paulatinamente, a cobertura alógena foi substituída por cobertura autógena definitiva. Foram realizadas oito enxertias autógenas no total (enxertias parceladas e reenxertias), iniciadas no $30^{\circ} \mathrm{dpq}$, até que todas as áreas cruentas fossem recobertas.

A face recebeu enxertia combinada, o que foi documentado fotograficamente e permitiu posteriores observações. Nesta região, no $42^{\circ}$ dpq (12 ${ }^{\circ}$ dia após a última substituição), os EAPGs nas regiões malares mostravam-se desprovidos de epiderme, deixando ver a derme alógena bem 
integrada e vascularizada (figura 1a). Neste mesmo dia, foi optado por não se retirar o material alógeno residual que cobria o leito da ferida, e sim por se colocar os enxertos autógenos em lâminas de pequena espessura (retirados do couro cabeludo) diretamente sobre a derme alógena jacente (enxertia combinada). No $16^{\circ}$ dia de pós-operatório, já era observada a pega completa do enxerto autógeno (figura 1b). É interessante notar que algumas áreas da região malar foram epitelizadas espontaneamente a partir das bordas das úlceras, por cima da derme alógena (figuras 1a e 1c). A alta hospitalar foi dada no $84^{\circ} \mathrm{dpq}$. O último registro fotográfico é de três meses após a enxertia combinada (figura 1c). Após essa data, foi perdido o contato com a paciente. 

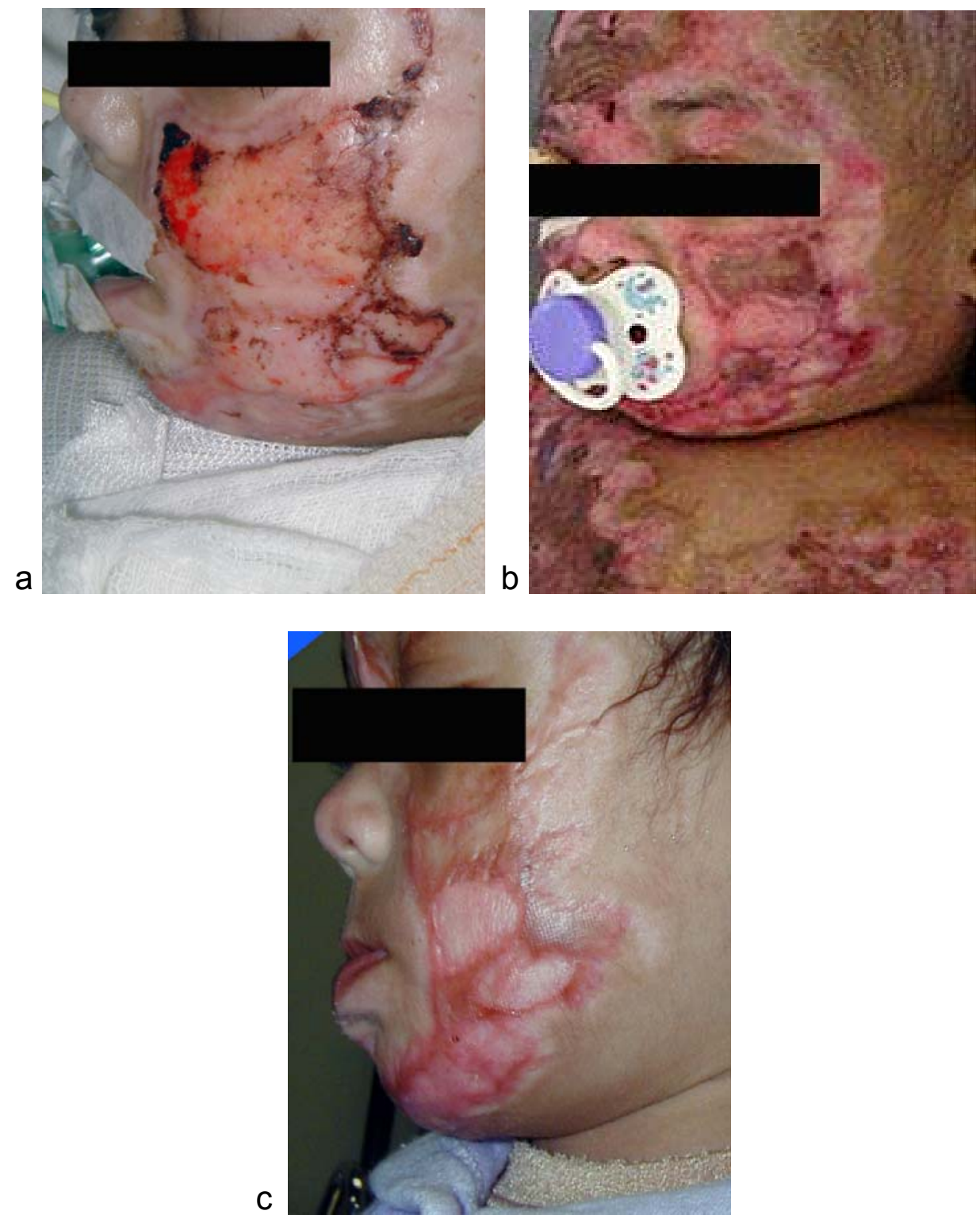

FIGURA 1. a) Enxerto alógeno em lâmina ( $12^{\circ}$ dia após enxertia). As áreas de cor rósea, pálida, correspondem à derme alógena vascularizada, já sem epiderme, pronta para receber o enxerto autógeno; as áreas de cor vermelho vivo correspondem ao tecido de granulação (áreas de perda do enxerto alógeno); as áreas de cor marrom escuro correspondem a restos epidérmicos. b) Enxerto combinado ( $16^{\circ}$ dia de pós-operatório). c) Enxerto combinado (três meses de pós-operatório) 


\section{Caso 2}

Indivíduo do sexo masculino, 24 anos, cor branca, foi vítima de colisão de automóveis com incêndio do veículo, teve queimaduras de $2^{\circ}$ e $3^{\circ}$ graus em tronco anterior e posterior, membros superiores, genitais, glúteos e membros inferiores, totalizando $63 \%$ de scq. Foi atendido inicialmente em outro hospital, dando entrada em nosso serviço já no $17^{\circ} \mathrm{dpq}$.

A partir do $7^{\circ} \mathrm{dpq}$, foi submetido à excisão de todas as queimaduras profundas ao nível da hipoderme, através de repetidos desbridamentos. No $22^{\circ} \mathrm{dpq}$ recebeu EAPGs fornecidos, através de importação, pelo Euro Skin Bank; estes foram colocados, inicialmente, nas pernas, em malha, expandidos na proporção de 1:3. Uma vez que no $12^{\circ}$ dia de pós-operatório (34 dpq), o EAPG estava bem integrado, vascularizado e já sem a epiderme (figura 2), foi optado por não removê-lo e, neste mesmo dia, cobri-lo diretamente com enxertos autógenos de pequena espessura, em malha 1:3 (enxertia combinada) (figura 3). A foto feita no $20^{\circ}$ dia após a enxertia mostra que não ocorreram perdas significativas dos enxertos (figura 4), e que grande parte das áreas vazadas da malha (áreas de "exposição" da derme alógena) já havia sido recoberta por epitélio. É notável que, com dois meses de pós-operatório, já se observava atenuação do padrão característico do enxerto em malha (figura 5).

No decorrer no tratamento foi utilizado um novo lote de enxertos alógenos, para complementação da cobertura de feridas residuais, desta vez fornecido pelo BT-IC-HCFMUSP. Seis enxertias autógenas (enxertias 
parceladas e reenxertias), iniciadas no $25^{\circ} \mathrm{dpq}$, foram realizadas no total, para cobertura das demais áreas cruentas. A alta hospitalar foi dada no $184^{\circ} \mathrm{dpq}$. A última documentação fotográfica é de 46 meses após a enxertia combinada (figura 6).

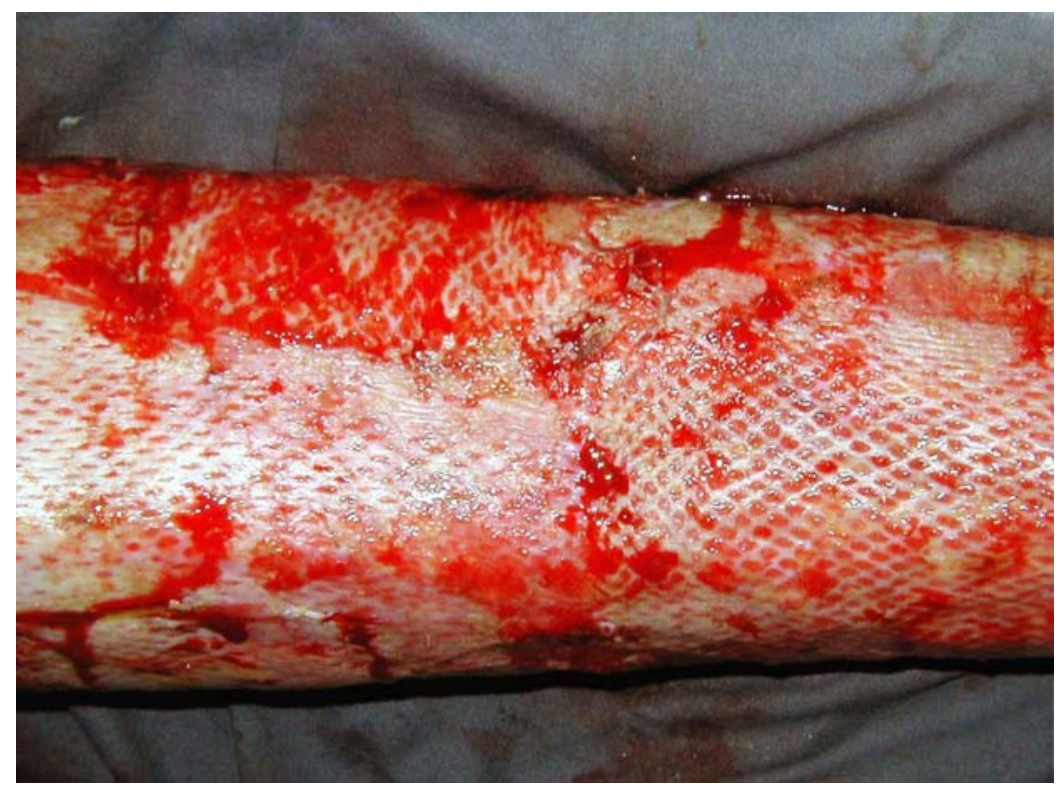

FIGURA 2. Enxerto alógeno em malha, já totalmente sem epiderme $\left(12^{\circ}\right.$ dia pós-enxertia)

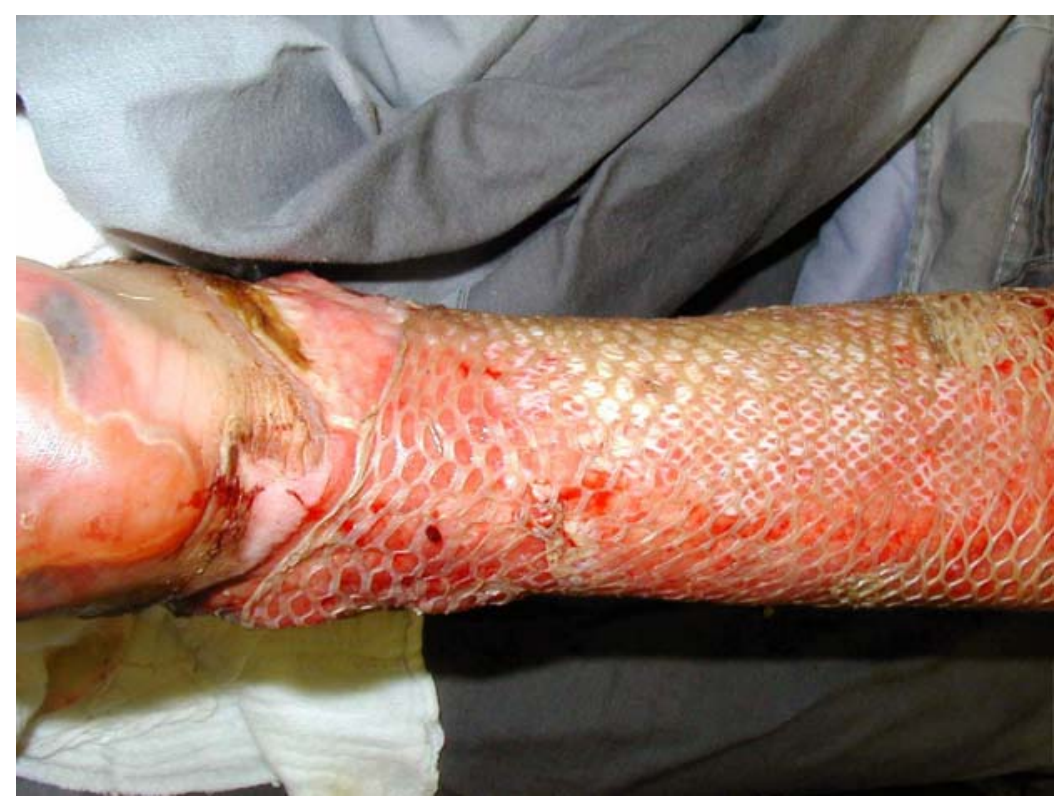

FIGURA 3. Enxerto alógeno em malha, já totalmente sem epiderme, recoberto por enxerto autógeno em malha (pós-operatório imediato) 


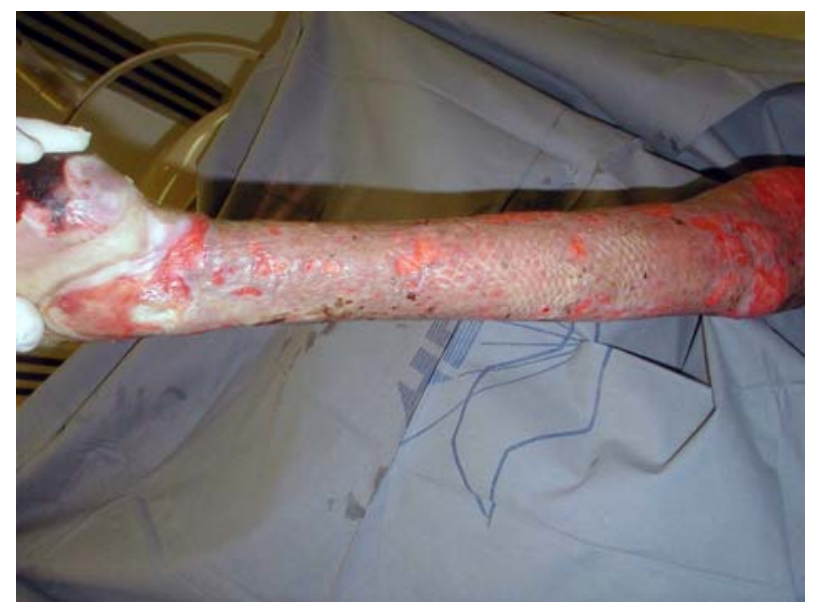

FIGURA 4. Enxerto combinado (20 dia de pós-operatório).

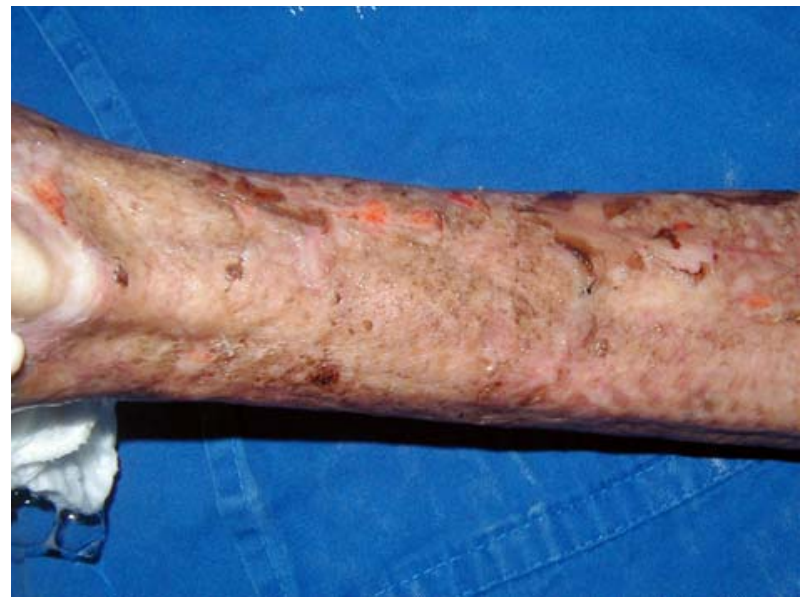

FIGURA 5. Enxerto combinado (2 meses de pós-operatório).

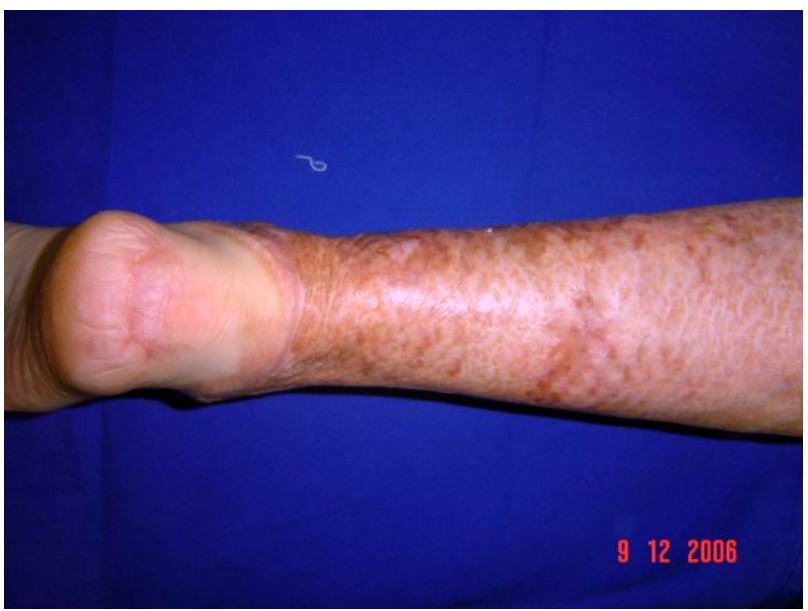

FIGURA 6. Enxerto combinado (46 meses de pós-operatório) 


\section{Caso 3}

Criança do sexo feminino, um ano e seis meses de idade, branca, vítima de queimadura química (teve as vestes embebidas por produto de limpar forno), foi internada com queimaduras de $2^{\circ}$ e $3^{\circ}$ graus envolvendo face ântero-medial de membro inferior esquerdo, incluindo coxa, joelho e perna, totalizando $3,5 \%$ de scq (figura 7 ). No $5^{\circ} \mathrm{dpq}$, foi submetida a desbridamento até o plano da fáscia (figura 8). Foram realizados curativos diários com papaína, para desbridamento químico complementar e preparo do leito da ferida (figura 9). No $12^{\circ} \mathrm{dpq}$ a ferida foi recoberta com EAPGs em lâminas, fornecidos pelo BT-IC-HCFMUSP (figura 10). No $9^{\circ}$ dia de pósoperatório, os EAPGs estavam integrados e a separação dermo-epidérmica estava adiantada (figura 11). No $14^{\circ}$ dia de pós-operatório $\left(26^{\circ} \mathrm{dpq}\right.$ ), os EAPGs (já completamente livres de epiderme) (figura 12) foram cobertos diretamente com enxertos autógenos em lâminas (figura 13). A perna recebeu enxertos de espessura parcial média retirados da coxa contralateral e o joelho recebeu enxerto de pele total retirado da região suprapúbica. No $7^{0}$ dia de pós-operatório, os enxertos combinados já estavam bem integrados e vascularizados (figura 14). A alta ocorreu no $35^{\circ} \mathrm{dpq}$. A última documentação fotográfica é de 27 meses após a enxertia combinada e mostra que a qualidade do tegumento resultante foi bastante aceitável do ponto de vista estético. Não houve a instalação de déficits funcionais, ainda que a profundidade e a localização da lesão inicial, bem como a idade da paciente tivessem sido favoráveis ao surgimento de formações cicatriciais patológicas (figuras 15, 16 e 17). 


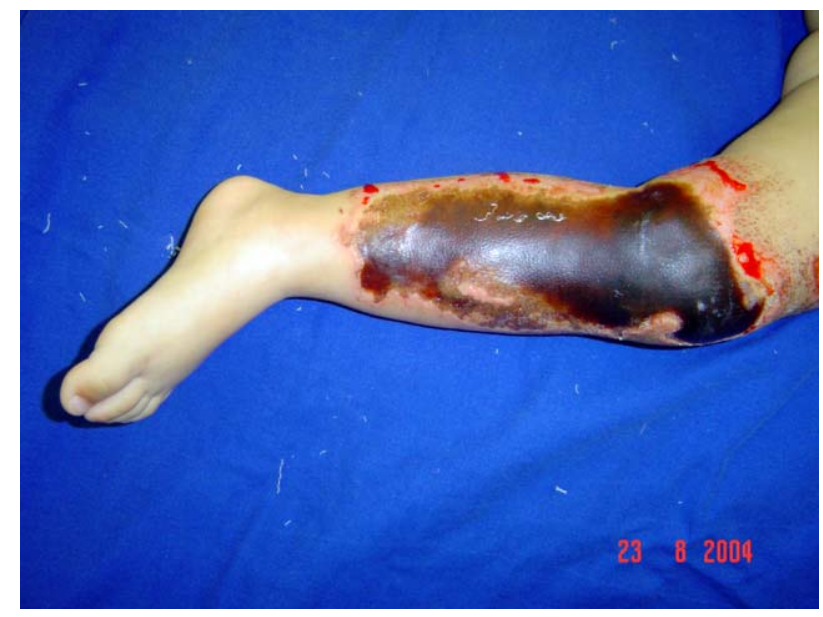

FIGURA 7. Queimadura química ( $\left.5^{\circ} \mathrm{dpq}\right)$.

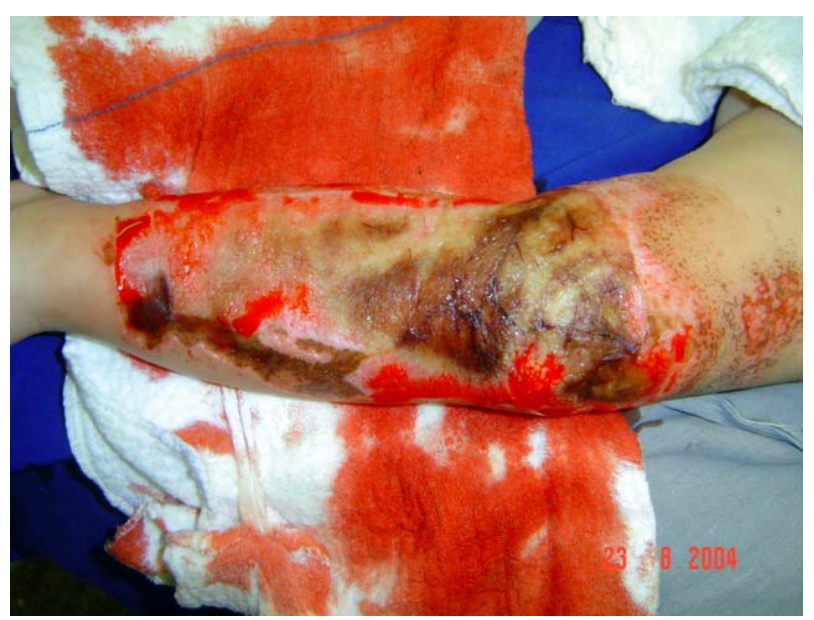

FIGURA 8. Acometimento da hipoderme, evidenciado após excisão tangencial $\left(5^{\circ} \mathrm{dpq}\right)$.

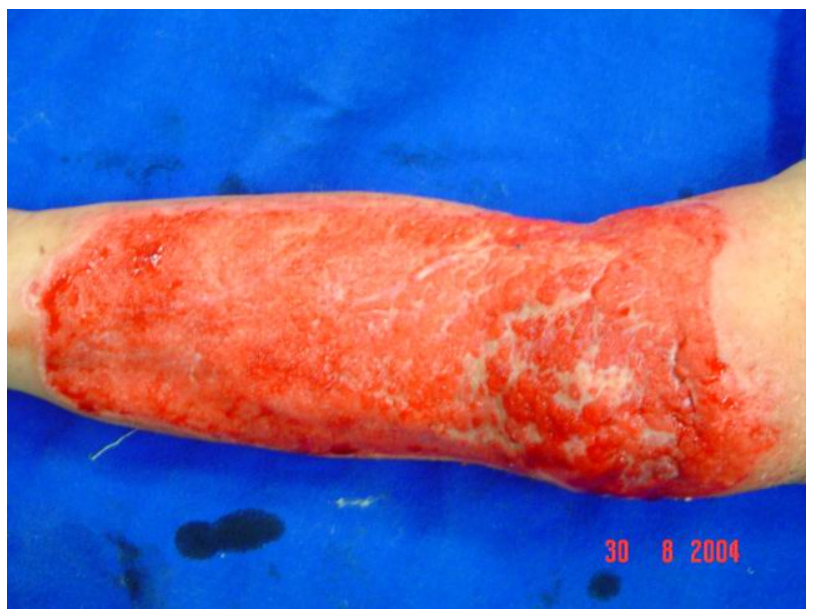

FIGURA 9. Ferida após desbridamento cirúrgico e preparo do leito com curativos diários com papaína $\left(12^{\circ} \mathrm{dpq}\right)$. 


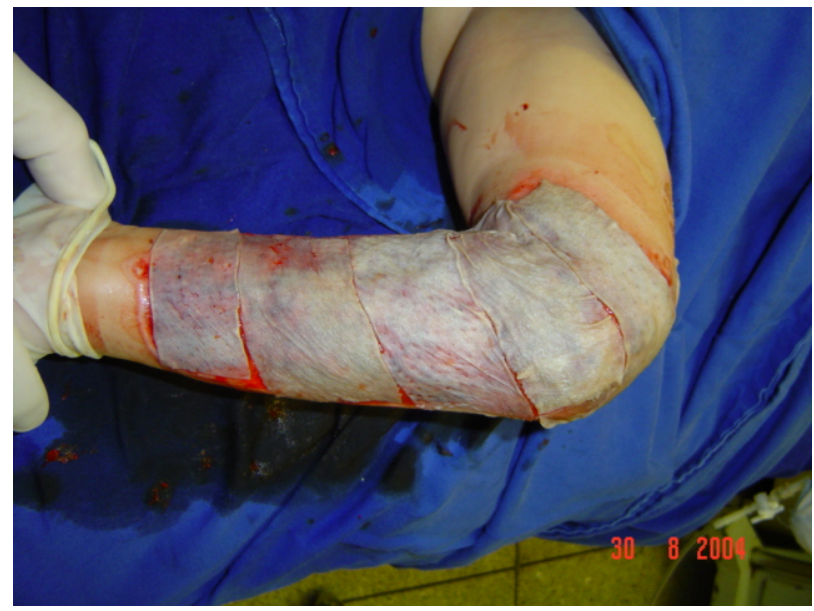

FIGURA 10. Enxertos alógenos em lâminas (pós-operatório imediato).

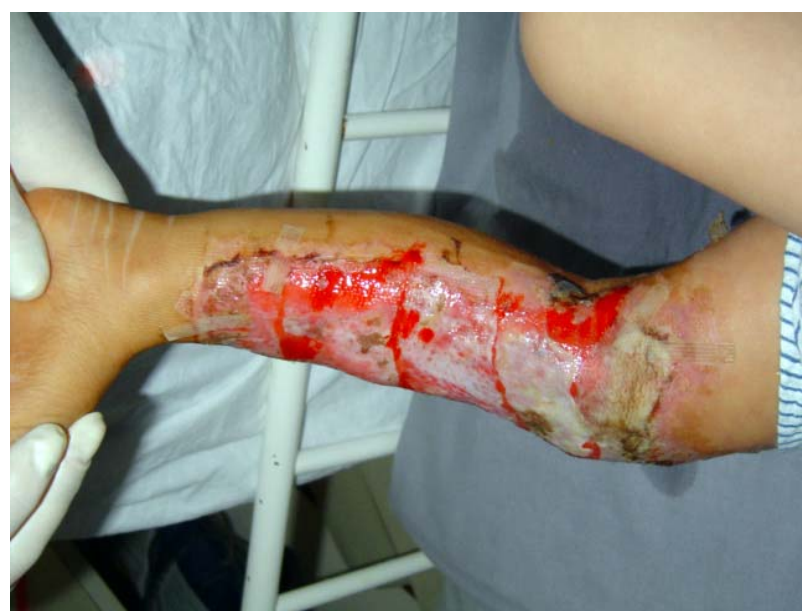

FIGURA 11. Enxertos alógenos em lâminas ainda com restos de epiderme (9 dia de pós-operatório).

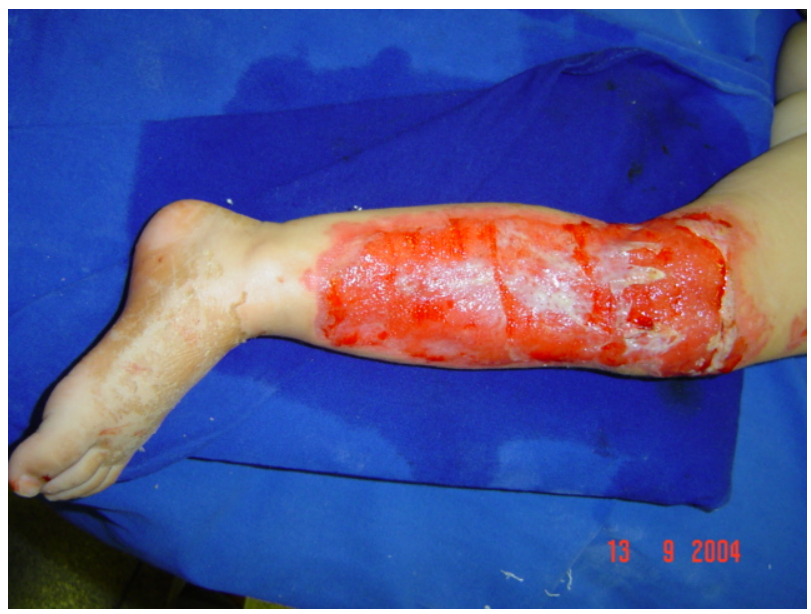

FIGURA 12. Enxertos alógenos em lâminas com a separação dermoepidérmica já completada ( $14^{\circ}$ dia de pós-operatório), prontos para receber os enxertos autógenos 


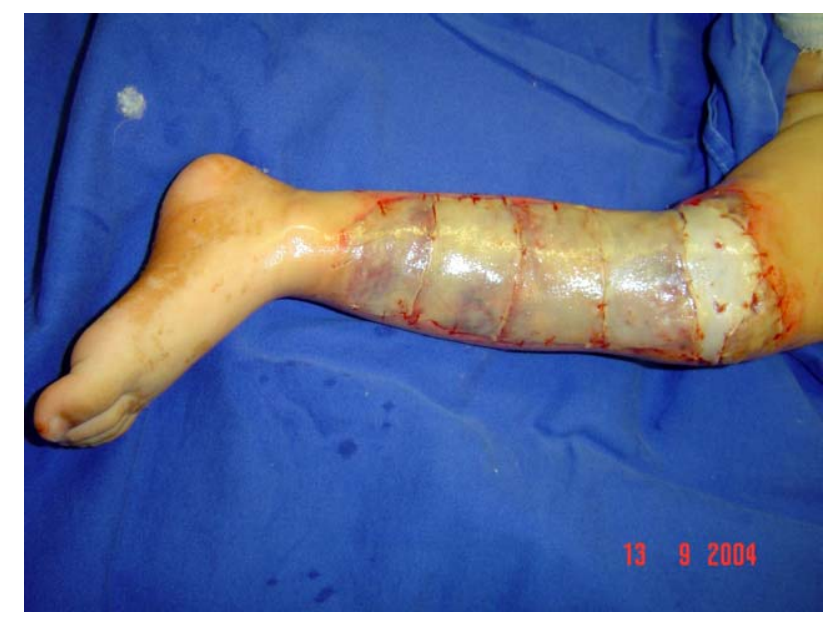

FIGURA 13. Enxertos combinados (pós-operatório imediato).

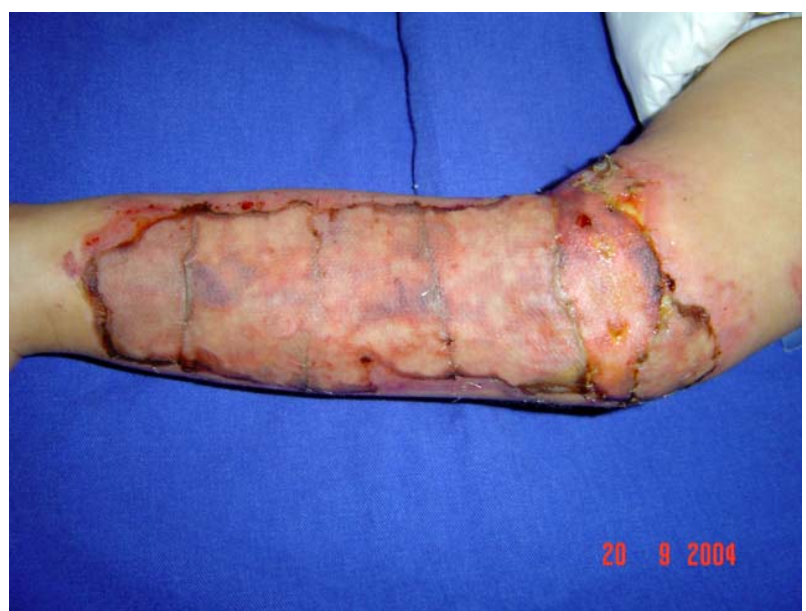

FIGURA 14. Enxertos combinados ( $7^{\circ}$ dia de pós-operatório).

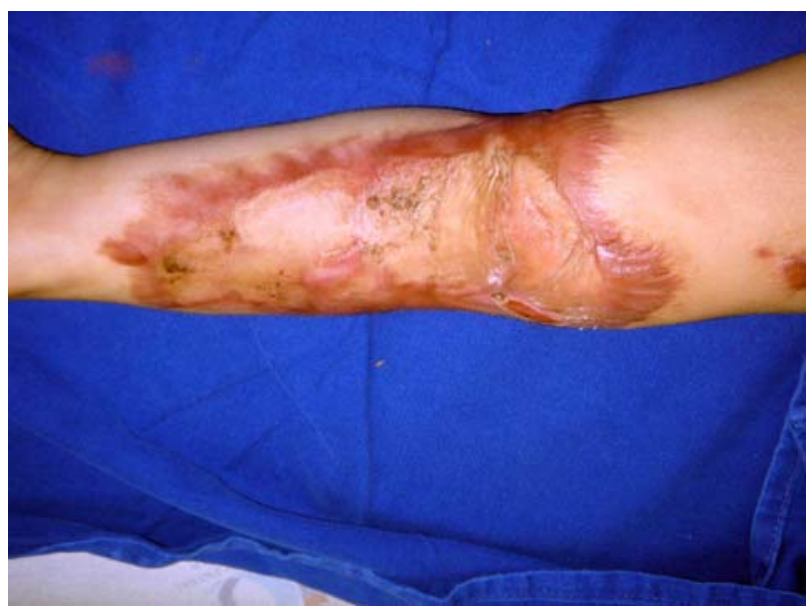

FIGURA 15. Enxertos combinados (6 meses de pós-operatório). 


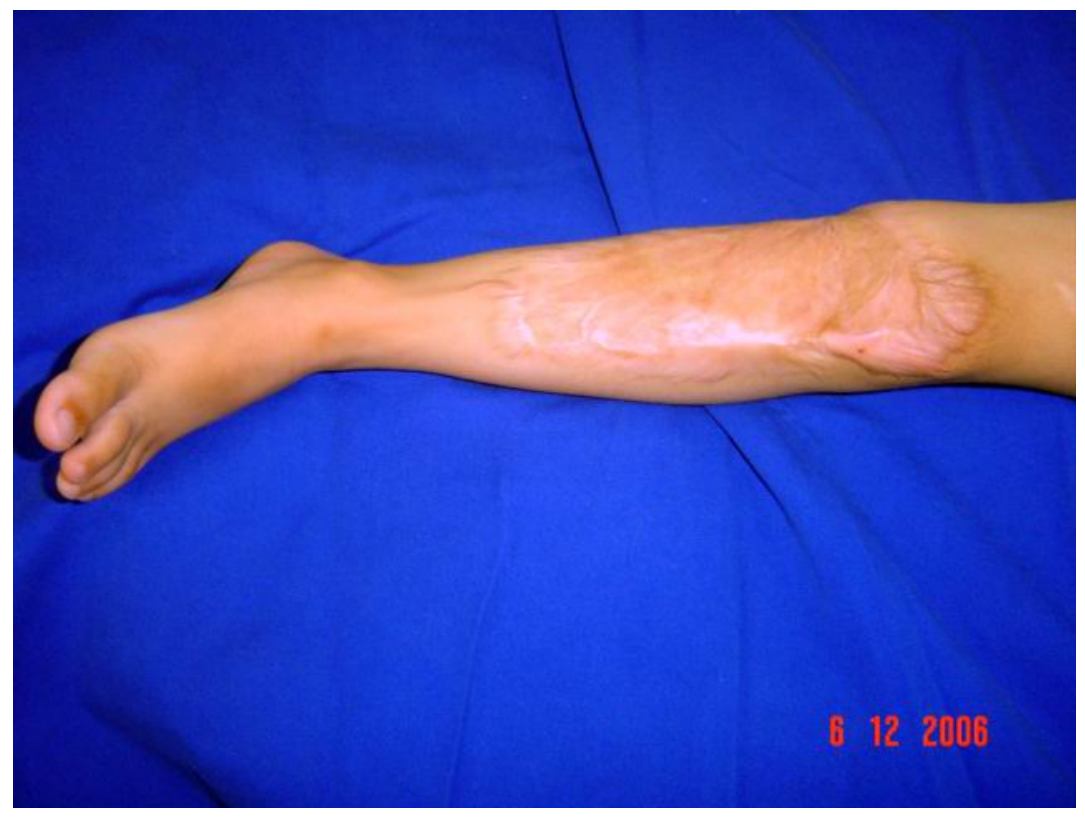

FIGURA 16. Extensão completa do joelho (27 meses de pós-operatório).

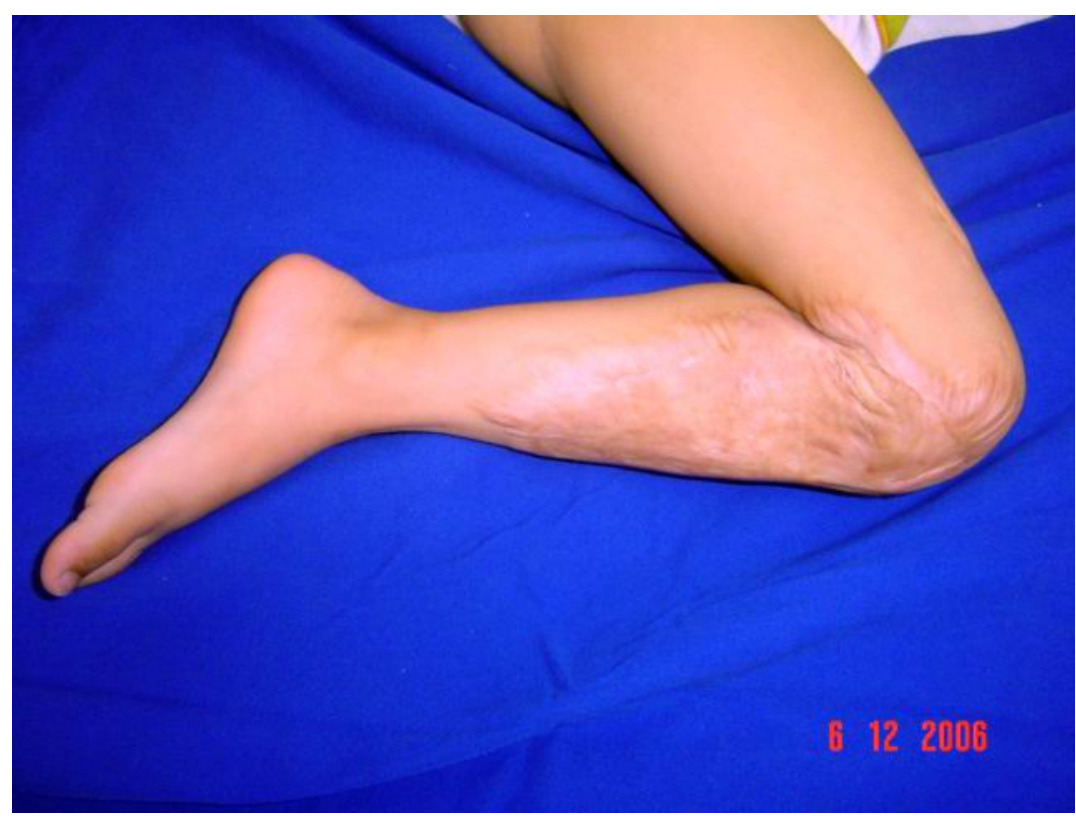

FIGURA 17. Flexão completa do joelho (27 meses de pós-operatório). 


\section{Caso 4}

Criança do sexo feminino, 1 ano e 3 dias de idade, branca, foi vítima de escaldadura por leite em $25 \%$ da superfície corporal, envolvendo tronco (faces anterior e posterior), membros superior e inferior esquerdos. $\mathrm{Na}$ primeira semana, ainda no hospital onde recebeu o primeiro atendimento, evoluiu com fasceíte necrotizante (que acometeu, inclusive, áreas nãoqueimadas) (figuras 18 e 19) e com isquemia em pé esquerdo

No $7^{\circ} \mathrm{dpq}$, foi admitida em nosso serviço com quadro de instabilidade respiratória, hemodinâmica e necrose do pé. No período entre o $10^{\circ}$ e $019^{\circ}$ dpqs, com estabilização do quadro clínico geral, foi submetida à excisão, ao nível da fáscia, dos tecidos desvitalizados (figuras 20 e 21), incluindo amputação transtibial em membro inferior esquerdo. Toda a área cruenta resultante foi recoberta, de imediato, com EAPGs regularmente fornecidos pelo BT-IC-HCFMUSP. No entanto, não houve a pega. Foi optado, então, por se manter curativos com carvão ativado por sete dias, como forma de preparo do leito da ferida (figura 22).

No $26^{\circ} \mathrm{dpq}$, já em condições locais mais propícias (figura 23), foi realizada nova enxertia alógena em malha 1:3 em toda a área cruenta, com material também fornecido pelo BT-IC-HCFMUSP. No $6^{\circ}$ dia de pósoperatório $\left(32^{\circ} \mathrm{dpq}\right)$ os EAPGs estavam bem integrados, com algumas áreas já sem a epiderme (figura 24). No $20^{\circ}$ dia de pós-operatório $\left(46^{\circ}\right.$ dpq), foi realizada enxertia autógena em malha 1:3 de toda a área cruenta 
(figura 26), diretamente por sobre o enxerto alógeno já totalmente sem epiderme (figura 25). No $72^{\circ} \mathrm{dpq}$, restavam pequenas úlceras residuais nas regiões occipital e sacral (figuras 27 e 28). A última documentação fotográfica (figura 29) é do dia da alta (1,6 mês de pós-operatório), que ocorreu no $94^{\circ} \mathrm{dpq}$. Após essa data, a paciente não mais compareceu aos retornos agendados. 


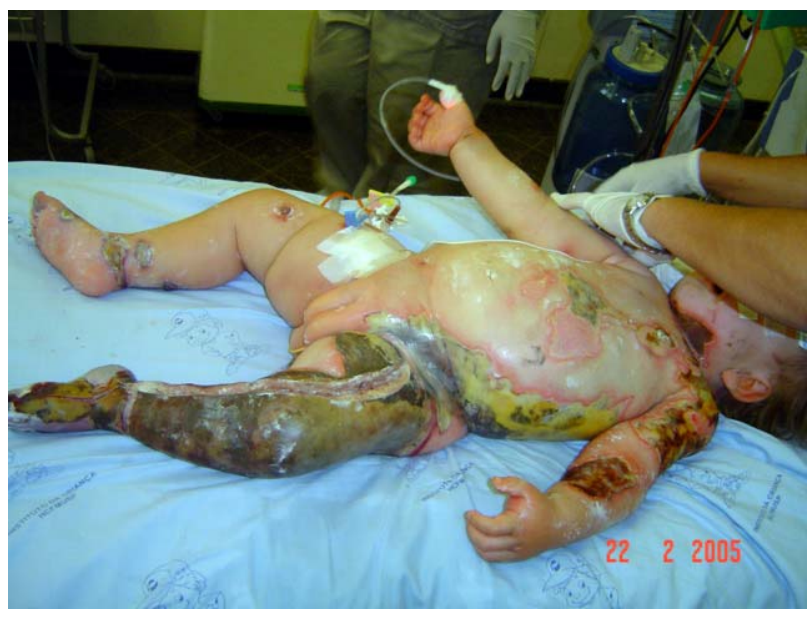

FIGURA 18. Visão geral das lesões tegumentares $\left(10^{\circ} \mathrm{dpq}\right)$.

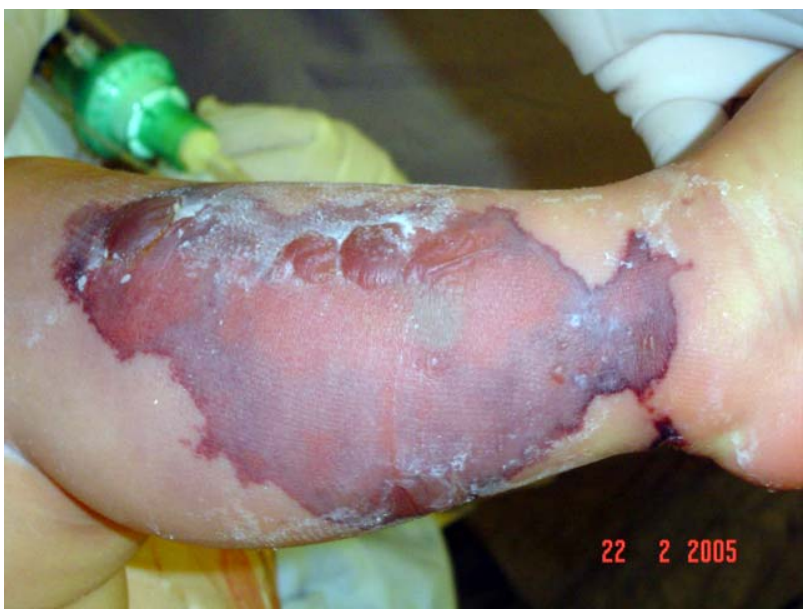

FIGURA 19. Necrose cutânea em área não-queimada (10 dpq).

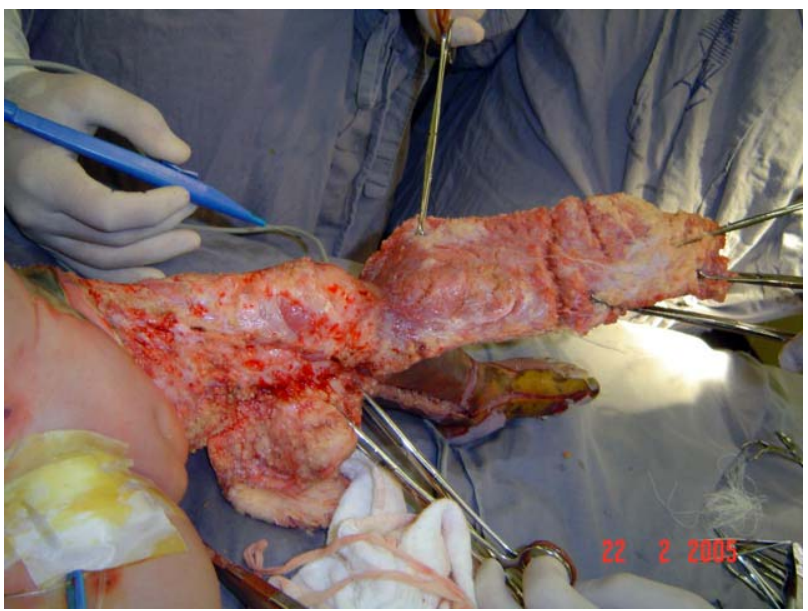

FIGURA 20. Necrosectomia realizada no plano epifascial $\left(10^{\circ} \mathrm{dpq}\right)$. 


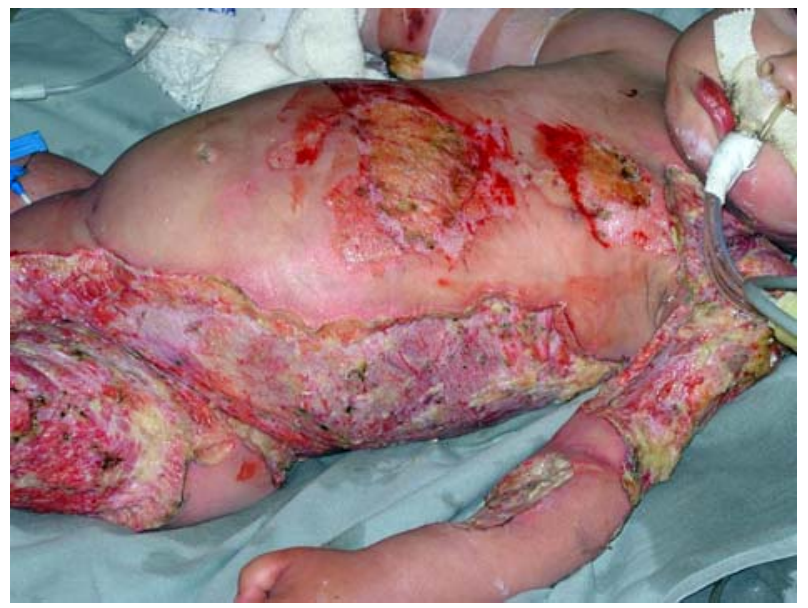

FIGURA 21. Visão geral das áreas cruentas após o primeiro desbridamento $\left(11^{\circ} \mathrm{dpq}\right)$.

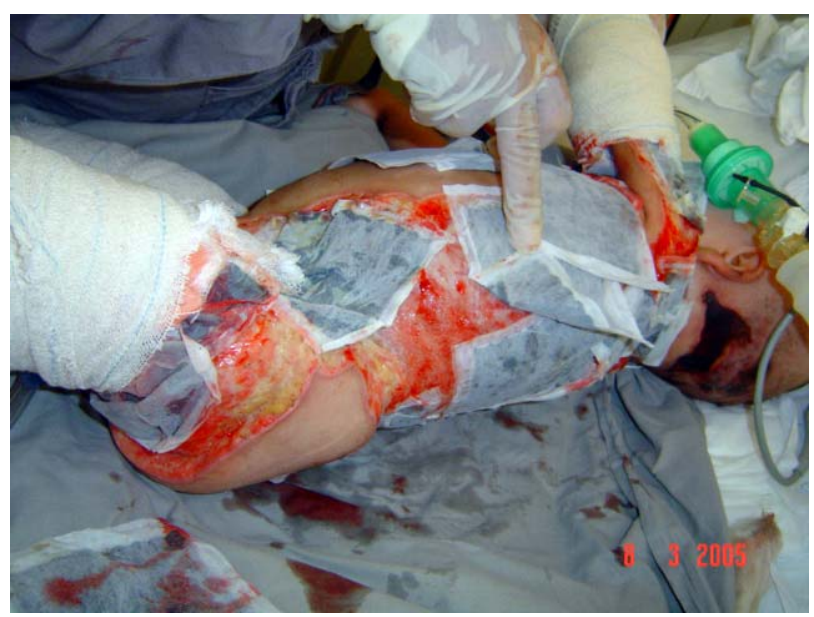

FIGURA 22. Preparo do leito da ferida com curativos de carvão ativado $\left(24^{\circ} \mathrm{dpq}\right)$.

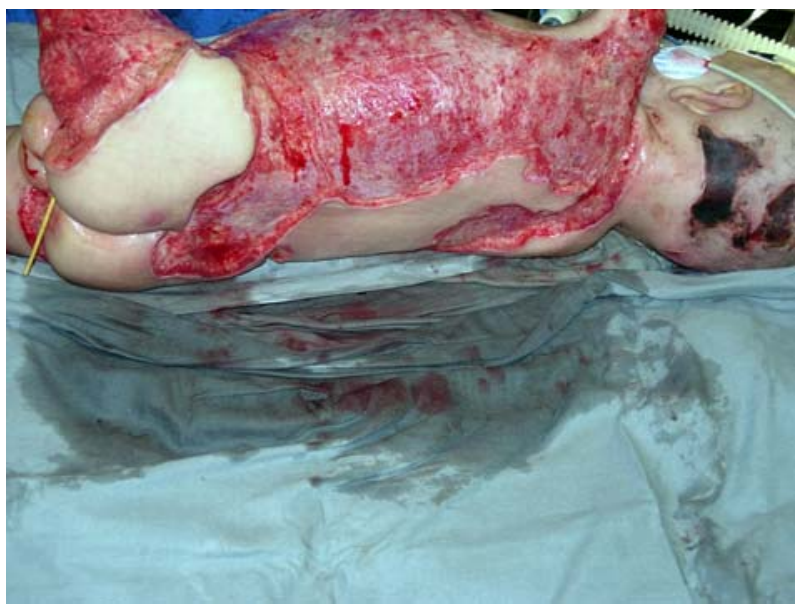

FIGURA 23. Aspecto do leito da ferida no dia da enxertia alógena definitiva $\left(26^{\circ} \mathrm{dpq}\right)$. 


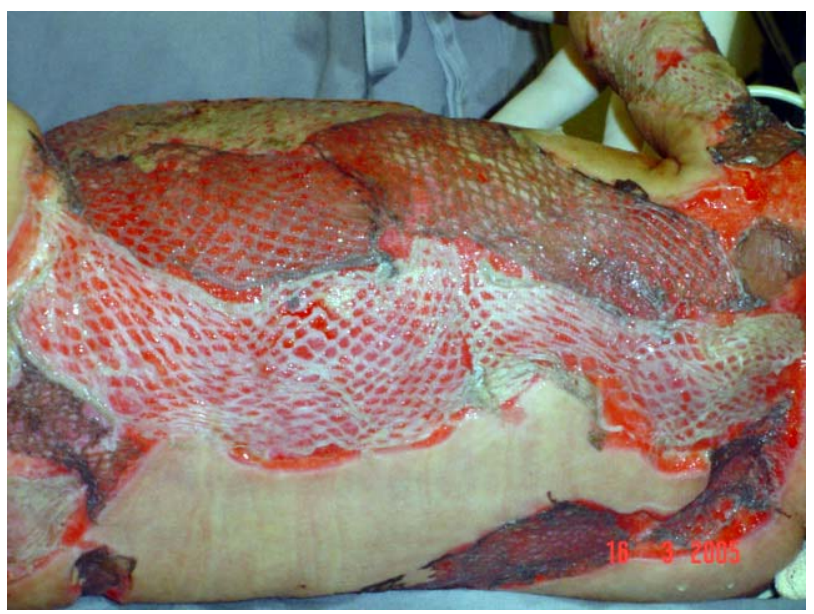

FIGURA 24. Enxertos alógenos em malha 1:3, com a separação dermoepidérmica em progressão ( $6^{\circ}$ dia de pós-operatório).

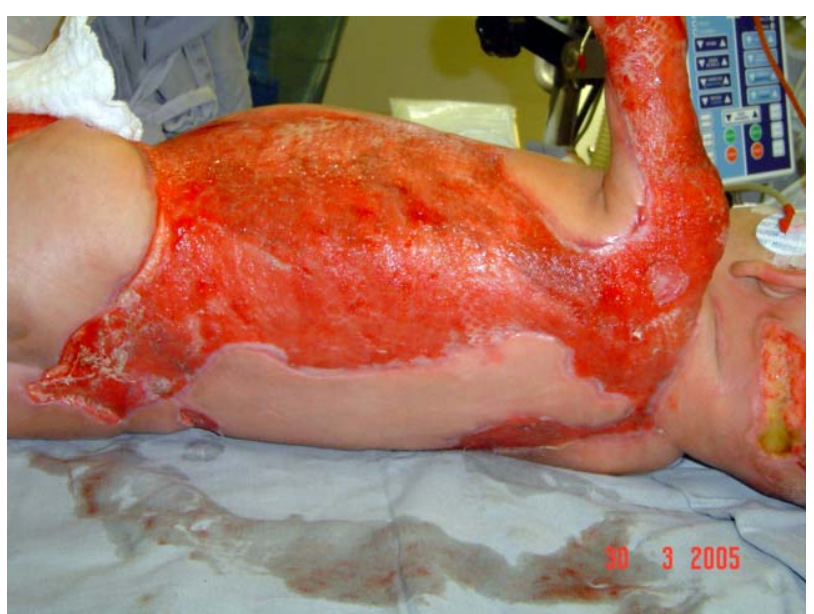

FIGURA 25. Aspecto dos enxertos alógenos (20 dia de pós-operatório) no dia da enxertia autógena.

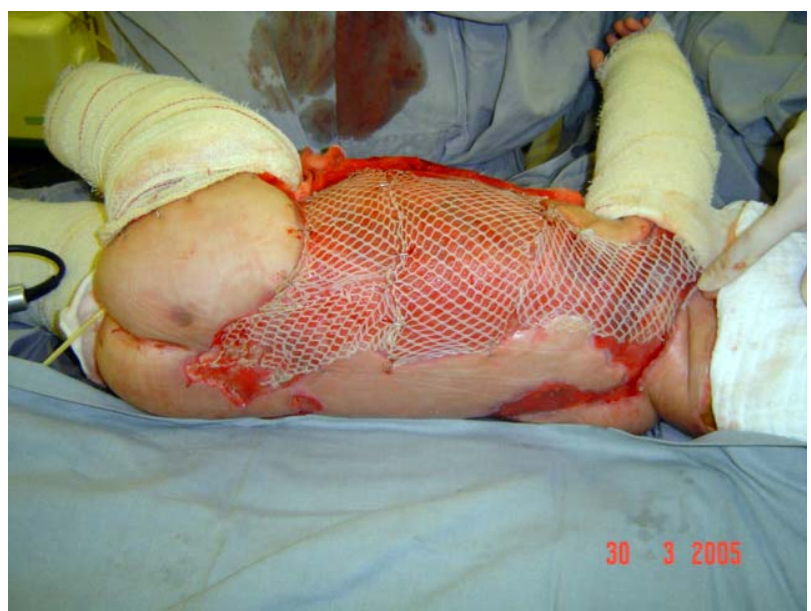

FIGURA 26. Enxertia combinada (pós-operatório imediato) 


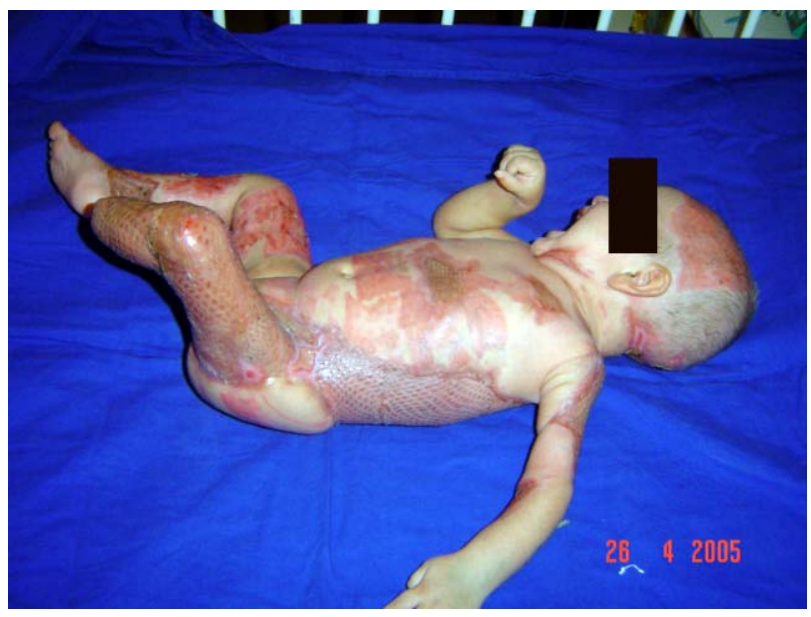

FIGURA 27. Visão geral do tegumento resultante do tratamento $\left(26^{\circ}\right.$ dia de pós-operatório).

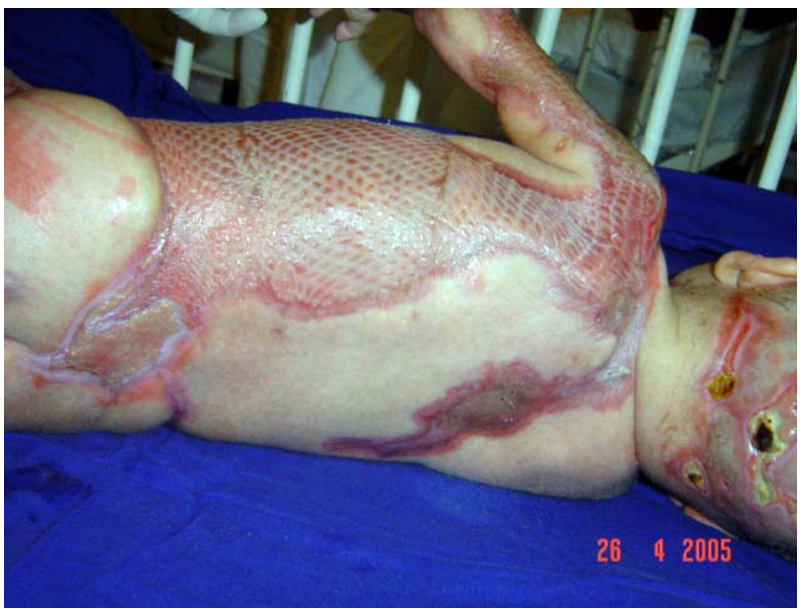

FIGURA 28. Enxertos combinados em dorso (26 dia de pós-operatório).

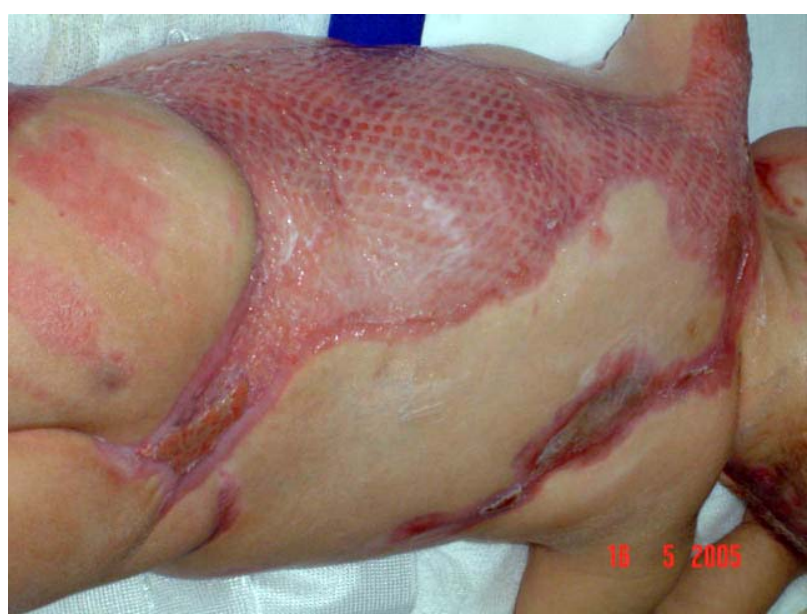

FIGURA 29. Enxertos combinados em dorso ( $48^{\circ}$ dia de pós-operatório). 
TABELA 1 - Resumo dos casos relatados

\begin{tabular}{c|l|l|l|l|l|c}
\hline Paciente & Idade & $\begin{array}{c}\text { Região } \\
\text { estudada }\end{array}$ & $\begin{array}{c}\text { Nível do } \\
\text { desbridamento }\end{array}$ & $\begin{array}{c}\text { Características } \\
\text { da enxertia } \\
\text { alógena }\end{array}$ & $\begin{array}{c}\text { Características } \\
\text { da enxertia } \\
\text { autógena }\end{array}$ & $\begin{array}{c}\text { Tempo de } \\
\text { seguimento }\end{array}$ \\
\hline 1 & 1 ano & Face & Hipoderme & $\begin{array}{c}\text { Em lâminas, } \\
\text { no } 28^{\circ} \mathrm{dpq}\end{array}$ & $\begin{array}{c}\text { Em lâminas, } \\
\text { no } 40^{\circ} \mathrm{dpq}\end{array}$ & 3 meses \\
\hline 2 & 24 anos & $\begin{array}{l}\text { Perna } \\
\text { direita }\end{array}$ & Hipoderme & $\begin{array}{c}\text { Em malha, } \\
\text { no } 22^{\circ} \mathrm{dpq}\end{array}$ & $\begin{array}{c}\text { Em malha, } \\
\text { no } 34^{\circ} \mathrm{dpq}\end{array}$ & 46 meses \\
\hline 3 & 1 ano & $\begin{array}{l}\text { Perna } \\
\text { esquerda }\end{array}$ & Fáscia & $\begin{array}{c}\text { Em lâminas, } \\
\text { no } 12^{\circ} \mathrm{dpq}\end{array}$ & $\begin{array}{c}\text { Em lâminas, } \\
\text { no } 26^{\circ} \mathrm{dpq}\end{array}$ & 27 meses \\
\hline 4 & 1 ano & $\begin{array}{l}\text { Tórax } \\
\text { lateral }\end{array}$ & Fáscia & $\begin{array}{c}\text { Em malha, } \\
\text { no } 26^{\circ} \mathrm{dpq}\end{array}$ & $\begin{array}{c}\text { Em malha, } \\
\text { no } 46^{\circ} \mathrm{dpq}\end{array}$ & 1,6 mês \\
\hline
\end{tabular}


Um enxerto de pele fresco alógeno, quando colocado sobre uma ferida com o leito em condições adequadas, pega, isto é, é revascularizado, como um enxerto fresco autógeno. Porém, dias depois, é percebida a rejeição do material alógeno pelo sistema imunológico do receptor, com o aparecimento de lentificação da circulação, seguida de cessação completa do fluxo sangüíneo, necrose e consumpção do enxerto ${ }^{20}$. Esta resposta, direcionada primariamente contra as células epidérmicas e endoteliais ${ }^{75}$, acontece uma a três semanas depois da aplicação ${ }^{76}$, em média, variando de acordo com o estado da imunidade do paciente queimado. Em decorrência disto, na prática clínica convencional, o enxerto alógeno é retirado (às vezes, sendo necessária a excisão cirúrgica, se o enxerto já estiver incorporado) antes que a rejeição progrida e cause dano adicional ao leito da ferida. Na seqüência, novos enxertos alógenos são colocados, ou mesmo enxertos autógenos, se já existirem áreas doadoras disponíveis.

O enxerto de pele alógeno preservado em glicerol adere ao leito da ferida e é revascularizado da mesma maneira ${ }^{20}$. No entanto, no período que se segue, do ponto de vista macroscópico, não se observa nada mais que ocorrência espontânea da separação dermo-epidérmica. Este fenômeno ocorre em torno de cinco a dez dias após a enxertia, tanto nos EACPs quanto nos EAPGs, e não parece estar relacionado à rejeição, mas sim 
associado à espessura do enxerto e ao processo de preservação ${ }^{45}$. Pruitt e Levine ${ }^{76}$ observaram que a separação dermo-epidérmica do material alógeno criopreservado ocorria quando o enxerto era retirado numa espessura maior que $0,381 \mathrm{~mm}$.

A aplicação dada ao EAPG aqui apresentada incorpora conceitos e procedimentos conhecidos. Porém, nos trabalhos com epiderme autógena cultivada (EAC) colocada sobre derme alógena $1,10,15,16,17,18$ é feita a excisão ou dermoabrasão para a retirada da epiderme. Pode ser destacado como uma particularidade prática do presente trabalho o fato de que a exposição da derme alógena foi obtida através da separação espontânea da epiderme, o que, teoricamente, preservaria maior quantidade de derme no leito, inclusive estruturas que participam da ligação dermo-epidérmica.

Em nosso estudo, foi observado que o "resíduo" de derme alógena preservada em glicerol que ficou aderido ao leito da ferida depois que a epiderme foi perdida prestou-se como substrato para o recebimento de cobertura epitelial autógena, seja um enxerto de espessura parcial ou mesmo a epiderme do receptor circunvizinha, que lentamente cresce a partir das margens e pode recobrir todo o "enxerto dérmico".

Para denominação do procedimento relatado no presente trabalho foi preferido o termo "enxerto combinado", ao invés de "enxerto composto", que vinha sendo utilizado por outros autores 1, 10, 15, 16, 17, 18 . A denominação "enxerto composto" já vem sendo empregada dentro da medicina para designar enxertos que levam múltiplas estruturas, como pele e cartilagem ou pele e gordura ${ }^{77,78}$. Segundo HOUAISS ${ }^{79}$, o termo "combinado" traz em 
suas acepções "que foi unido, que foi objeto de combinação, que foi resultado de planejamento, que se apresenta harmonizado, consoante, ajustado", idéias estas mais afins com o que de fato ocorre com os enxertos.

Procedimentos muito semelhantes aos realizados em nosso trabalho foram relatados por WAINWRIGHT ${ }^{80,81}$, LATTARI et al. ${ }^{82}$, MUNSTER et al. ${ }^{83}$ e CALCUTT et al. ${ }^{84}$. A diferença foi que estes autores empregaram o AlloDerm ${ }^{\circledR}$ (LifeCell Corp., Branchburg, NJ) como substrato dérmico para recebimento dos enxertos autógenos. Alloderm® é um material industrializado, comercializado como equivalente dérmico liofilizado por congelamento, que consiste de matriz dérmica acelular, obtida a partir do processamento direto de pele de cadáver fresca, tratada para remoção da epiderme e do material celular da derme. WAINWRIGHT et al. ${ }^{81}$ informaram que os resultados obtidos com o uso de auto-EPEPs mais finos em combinação imediata com AlloDerm ${ }^{\circledR}$ foram equivalentes aos obtidos com auto-EPEPs de maior espessura. Embora estejam embasados essencialmente nos mesmos princípios, o emprego da enxertia combinada com EAPG distingue-se da enxertia combinada com AlloDerm ${ }^{\circledR}$ pelo fato de que a primeira apresenta custo financeiro significativamente menor, embora necessite ser realizada em dois tempos cirúrgicos.

Nos casos aqui apresentados, o emprego da enxertia de pele combinada pareceu contribuir, em grau considerável, para a redução do tal "déficit de derme" decorrente da queimadura. Mesmo nos casos três e quatro (tabela 1), nos quais a reduzida idade das pacientes e a maior profundidade das lesões iniciais eram fatores de risco para o surgimento de 
formações cicatriciais exuberantes, a qualidade do tegumento resultante foi bastante satisfatória, como atesta a documentação fotográfica apresentada. Seria relevante, em estudos posteriores, avaliar as áreas reconstituídas com enxertos combinados quanto à sensibilidade e à produção de sebo e suor.

Também é de se destacar o fato de que no caso dois, aos dois meses de pós-operatório, pôde ser observada a atenuação do padrão característico do enxerto em malha na área que recebeu enxertos combinados (figura $2 \mathrm{~d}$ ). Este fenômeno sugere que o uso do EAPG em malha 1:1,5 (ou 1:3, pouco aberta) teria como vantagens um maior rendimento do material e maior facilidade para a pega, sem, no entanto, haver prejuízo da qualidade da cobertura resultante; benefícios adicionais seriam conseguidos com enxertos alógenos mais espessos.

É sabido que o elemento dérmico do alo-EPEP não é inerte do ponto de vista imunológico. No entanto, apesar da perda da epiderme, a porção dérmica do enxerto segue vascularizada, remanescente sobre o leito da ferida, sem qualquer sinal de rejeição. Além de uma eventual tolerância decorrente da menor competência imunológica do paciente queimado, outros dois potenciais mecanismos poderiam ser considerados na explicação deste fenômeno ${ }^{10}$.

O primeiro mecanismo seria a ocorrência de atenuação da imunorreatividade do alo-EPEP como resultado do processo de preservação em $\mathrm{si}^{42}$. A base desse efeito é desconhecida, mas pode ser relacionada a alterações dos antígenos de superfície das células, induzidas pelo processamento ${ }^{85}$. 
O segundo mecanismo diz respeito ao fato de que somente a falta de histocompatibilidade é insuficiente para causar a rejeição do tecido alógeno transplantado. É necessária a presença antígenos do complexo de histocompatibilidade principal (CHP) de classe II no tecido alógeno para dar início à agressão por parte do receptor ${ }^{86}$. A remoção ou supressão desses antígenos dos tecidos enxertados é uma medida efetiva para obtenção da sobrevivência do enxerto alógeno em longo prazo ${ }^{86}$.

A primeira fase da rejeição consiste no reconhecimento, pelas células do receptor, das células alógenas como não-próprias. Os elementos que são reconhecidos são as moléculas CHP. O CHP inclui vários loci gênicos que dirigem a expressão de moléculas encontradas na superfície das células, e que, como o próprio nome diz, são relacionadas à função do aloreconhecimento por parte do sistema imunológico ${ }^{87}$. Existem dois tipos distintos de moléculas do CHP: os antígenos de classe I e de classe II. Essas duas classes diferem entre si tanto em estrutura quanto em função. Os antígenos de classe I são expressos na superfície de todas as células nucleadas; a expressão dos antígenos de classe II, ao contrário, é restrita, estando presente, por exemplo nas células linfóides. A maioria das outras células, normalmente, não expressam os antígenos de classe II; no entanto, algumas células podem ser induzidas a expressar antígenos de classe II transitoriamente ${ }^{87}$.

As únicas células presentes na derme que, em circunstâncias normais, têm a capacidade de expressar antígenos de classe II são as células endoteliais e as células de Langerhans da epiderme que reveste os anexos ${ }^{88}$. 
As células de Langerhans são células derivadas da medula óssea e não constituem exceção ao restrito grupo de células que constitucionalmente expressam antígenos de classe II, uma vez que têm função equivalente aos dos fagócitos mononucleares e são, em parte, responsáveis pela vigilância imunológica da epiderme ${ }^{89}$. Queratinócitos, melanócitos e fibroblastos normalmente não expressam antígenos de classe $\mathrm{II}^{90}$.

Cuono ${ }^{10}$ postulou que a remoção do componente epidérmico do aloEPEP integrado ao leito da ferida eliminaria a maioria das células que, constitucionalmente, expressam antígenos do CHP de classe II, deixando para trás um leito dérmico alógeno vascularizado que não é capaz de iniciar a resposta de rejeição. As células endoteliais seriam de menor importância nesse processo, porque na seqüência fisiológica de integração vascular de um EPEP, os vasos sangüíneos nele presentes normalmente degeneram e são substituídos por outros vasos que crescem a partir do leito receptor ${ }^{91}$.

O sucesso funcional desse material remanescente, de origem alógena, desprovido de atividade metabólica, como substituto, pode estar relacionado à natureza essencialmente fibrosa (e não celular) da derme. Ao contrário do que ocorre em outros tecidos (onde a matriz extracelular é quase inexistente), o tecido conjuntivo que compõe a derme apresenta matriz rica e abundante, a qual contem elementos importantes do ponto de vista estrutural e funcional ${ }^{89}$. A estrutura, em si, da matriz extracelular da derme tem sido considerada como responsável por um dos papéis centrais na condução da reparação tecidual ${ }^{92}$ por orientar o comportamento das células da pele em todo o processo ${ }^{69,93,94}$. Estudos in vitro mostraram que o 
ácido hialurônico, um dos componentes estruturais da matriz dérmica, apresenta quimiotaxia para células mesenquimais e induz proliferação celular; in vivo, foi demonstrado que tem o poder de aumentar a proliferação epitelial e apresenta profunda atividade pró-angiogênica ${ }^{92}$. Tais dados apontam explicações para o sucesso relatado por diversos autores com o emprego dos EAPGs, enxertos não-viáveis, qual seja a situação para a qual foram indicados.

O bom desempenho da derme depende em grande parte da integridade da matriz extracelular e de seus componentes. O processo de preservação em glicerol não danifica essas estruturas, nem tampouco são elas alvo de significativa rejeição. A incapacidade das células do receptor em gerar resposta imune contra o componente dérmico do enxerto alógeno pode ser atribuída à falta relativa de antigenicidade da matriz dérmica. Colágeno e glicosaminoglicanas encontradas na matriz são capazes de gerar resposta imunológica apenas discreta ${ }^{95,96 .}$

O destino exato da derme alógena quando combinada com enxerto autógeno ainda não é bem conhecido. Uma vez integrada, a derme alógena remanescente é invadida por fibroblastos, células endoteliais e outras, provenientes do receptor ${ }^{20,92}$. A matriz dérmica do alo-EPEP atuaria como arcabouço orientador para distribuição destas células que, por sua vez, modificariam a matriz e a dotariam de material autógeno, incorporando-a totalmente. Em estudo experimental foi possível detectar a derme alógena até noventa dias após a enxertia, sem sinais histológicos de rejeição; biópsias das áreas providas de epitélio autógeno por sobre a derme alógena demonstraram a presença de junção dermo-epidérmica de aspecto normal ${ }^{97}$. 
$\mathrm{Na}$ era atual da preservação de tecidos, é importante que os cirurgiões saibam fazer o uso racional da "pele de banco" e que sejam capazes de calcular as relações de risco/benefício para as diferentes metodologias de preservação e indicações clínicas ${ }^{41}$. Numa situação hipotética, em condições semelhantes, a utilização de um EACP traz sempre mais riscos que a utilização de um EAPG. É considerado contra-indicado o uso de enxertos viáveis, como os criopreservados, para tratamento de lesões que não acarretam risco de morte, como queimaduras de pequena extensão ou outras úlceras ${ }^{98}$, devido ao risco residual de infecção cruzada.

No entanto, no caso dos EAPGs, exatamente por não existir nenhuma exigência de manutenção da viabilidade das células da pele, o método de preservação aplicado produz também desinfecção, inclusive viral, de maneira efetiva. Isto amplia a possibilidade de sua utilização dentro de padrões de biossegurança aceitáveis, e abre a possibilidade, por exemplo, do uso de enxertos combinados com EAPG para "preenchimento" de defeitos surgidos da liberação retrações cicatriciais, no tratamento de seqüelas de queimaduras. 
1. Após a separação dermo-epidérmica espontânea, o componente dérmico do enxerto de pele de espessura parcial alógeno preservado em glicerol, que permanece integrado ao leito da ferida, constituiu-se em substrato adequado para o recebimento de enxerto de pele de espessura parcial autógeno.

2. Os tegumentos resultantes da enxertia combinada mostraram-se estáveis e duráveis, dentro do período de seguimento dos casos apresentados. 
1. Sheridan R. Comprehensive treatment of burns. Curr Probl Surg. 2001; 38: 641-756.

2. McCauley RL. The Skin Bank. In Herndon DN, editor. Total Burn Care. Londres: WB Saunders; 1996. p. 159-63.

3. Klein L, Rudolph R. 3 H-collagen tumover in skin grafts. Surg Gynecol Obstet. 1972; 135: 49-57.

4. Mensik I, Lamme EN, Brychta P. Depth of the graft bed influences splitskin graft contraction. Acta Chir Plast. 2003; 45(3): 105-8.

5. O'Connor N, Mulliken J. Grafting of burns with cultured epithelium from autologous epidermal cells. Lancet 1981; 1: 75-8.

6. Gallico GC 3d, O'Connor NE, Compton CC, Kehinde EO, Green H. Permanent coverage of large burn wounds with autologous cultured human epithelium. N Engl J Med. 1984; 311: 448-51.

7. Hafemann B, Ensslen S, Erdmann C. Use of collagen/elastin membrane for the tissue engineering dermis. Burns 1999; 25: 373-84.

8. Woodley DT, Peterson HD, Herzog SR et al. Burn wounds resurfaced by cultured epidermal autografts show abnormal reconstitution of anchoring fibrils. JAMA 1988; 259: 2566-71. 
9. Cuono CB, Langdon R, Mcguire J. Use of cultured epidermal autografts and dermal allografts as skin replacement after burn injury. Lancet 1986; 1: 1123-24.

10. Cuono CB, Langdon R, Birchall N, Barttelbort S, Mcguire J. Composite autologous-allogeneic skin replacement: development and clinical application. Plast Reconstruct Surg. 1987; 80: 626-35.

11. Langdon, Cuono $\mathrm{CB}$, Birchall $\mathrm{N}$ et al. Reconstitution of structure and cell function in human skin grafts derived from cryopreserved allogeneic dermis and autologous cultured keratinocytes. J Invest Dermatol. 1988; 91: 478-85.

12. Gibson T, Medawar PB. The fate of skin homografts in man. $J$ Anat. 1943; 77:299 apud Furnas DW 1987, p. 636.

13. Medawar PB. A second study of the behavior and fate of skin homografts in rabbits. J Anat. 1945; 79: 157 apud Furnas DW 1987, p. 636.

14. Jackson D. A clinical study of the use of skin homografts for burns. $\mathrm{Br} \mathrm{J}$ Plast Surg. 1955; 7: 26 apud Furnas DW 1987, p. 636.

15. Heck EL, Bergstresser PR, Baxter, CR. Composite skin graft: frozen dermal allografts support the engraftment and expansion of autologous epidermis. J Trauma 1985; 25: 106-12.

16. Schiozer WA, Hartinger A, Von Donnersmarck GH, Muhlbauer W. Composite grafts of autogenic cultured epidermis and glycerol-preserved allogeneic dermis for definitive coverage of full thickness burn wounds: case reports. Burns 1994; 20: 503-7. 
17. McKay I, Woodward B, Wood K, Navsaria HA, Hoekstra H, Green H. Reconstruction of human skin from glycerol preserved allodermis and cultured keratinocytes. Burns 1994; 20: S19-22.

18. Druecke D, Steinstraesser L, Homann HH, Steinau HU, Vogt PM. Current indications for glycerol-preserved allografts in the treatment of burn injuries. Burns 2002; 28 (Suppl 1): S26-30.

19. Herson MR, Mathor MB, Altran S, Capelozzi VL, Ferreira MC. In vitro construction of a potential skin substitute through direct human keratinocyte plating onto decellularized glycerol-preserved allodermis. Artificial Organs 2001; 25(11): 901-6.

20. Burd A, Lan PK, Lau H. Allogenic skin: transplant or dressing? Burns 2002; 28(4): 358-66.

21. Reverdin JL. Sur la greffe epidermique. CR Acad Sc (Paris) 1871; 73: 1280 apud Burd A 2002, p. 363.

22. Reverdin JL. De la greffe epidermique. Arch Gen Med. 1872; 19 (Suppl. 6): 276 apud Burd A 2002, p. 363.

23. Lawson G. Cases of skin grafting. Lancet 1870; 2: 567 apud Burd A 2002, p. 363.

24. Pollock G. Cases of skin grafting and skin transplantation. Trans Clin Soc London 1871; 4: 37 apud Burd A 2002, p. 363.

25. Girdner JH. Skin grafting with skin grafts taken from the dead subject. Med Rec New York 1888; 20: 119-20 apud Burd A 2002, p. 363. 
26. Blome-Eberwein S, Jester A, Kuentsche M, Raff T, Germann G, Pelzer M. Clinical practice of glycerol preserved allograft skin coverage. Burns 2002; 28 (Suppl.1): 10-12.

27. Tier WC, Sell KW. United States Navy skin bank. Plast Reconstruct Surg. 1968; 41: 543-48.

28. Brown JB, Fryer MP, Randall P, Lu M. Post mortem homografts as biological dressings for extensive burns and debrided areas. Ann Surg. 1953; 138: 618-23 apud Mccauley RL 1996.

29. Kagan RJ. Human skin banking: past, present and future. In: Phillips GO, Strong DM, von Versen R, Nather A, editores. Advances in tissue banking. Vol 2. River Edge, NJ: World Scientific; 1998. p. 297-321.

30. Hermans $\mathrm{MH}$. Clinical experience with glycerolpreserved donor skin treatment in partial thickness burns. Burns 1989; 15: 57-9.

31. Mackie DP. The Euro skin bank: development and application of glycerol-preserved allografts. J Burn Care Rehabil 1997; 18: S7-9.

32. DeBackere ACJ. Euro Skin Bank: large scale skin-banking in Europe based on glycerol-preservation of donor skin. Burns 1994; 20 (Suppl 1): S4-S9.

33. Brychta P. EATB: Standards for banking of biologic skin substitutes (BSS). Cell Tissue Bank. 2002; 3: 59-71.

34. Carrel A. Rejuvenation of cultures of tissues. JAMA 1911; 57: 1611 apud DeBono R 1998, p. 82.

35. Matthews DN. Storage of skin for autogenous grafts. Lancet 1945; 1: 775 apud DeBono R 1998, p. 82. 
36. Donaldson RC, Payne J, Hershey FB. Effects of storage on enzyme activity and viability of skin. Surg Gynecol Obstet. 1960; 110:1-4.

37. DeBono R, Rao GS, Berry RB. The survival of human skin stored by refrigeration at 4 degrees $C$ in McCoy's $5 \mathrm{~A}$ medium: does oxygenation of the medium improve storage time? Plast Reconstr Surg. 1998; 102(1): 78-83.

38. Cochrane ET. The low temperature storage of skin: a preliminary report. Br J Plast Surg. 1968; 21(2): 118-25.

39. Baxter C, Aggarwal S, Diller KR. Cryopreservation of skin: a review. Transplant Proc. 1985; 17(6, Suppl. 4): 112-20.

40. Blondet R, Gibert-Thevenin MA, Pierre C, Ehrsam A. Skin preservation by programmed freezing. Br J Plast Surg. 1982; 35(4): 530-6.

41. Kearney J. Quality issues in skin banking: a review. Burns 1998; 24: 299-305.

42. Abbot WM, Pappas AM. Comparative studies on fresh and preserved skin: fundamental biologic differences in behavior as grafts. Ann Surg. 1970; 172: 781-86.

43. Bondoc CC, Burke JF. Clinical experience with viable frozen human skin and a frozen skin bank. Ann Surg. 1971; 174: 371-82.

44. Lehr HB, Berggren RB, Lotke PA, Coriell LL. Permanent survival of preserved skin autograft. Surgery 2002; 56: 742-96.

45. Robb EC, Bechmann N, Plessinger RT, Boyce ST, Warden GD, Kagan RJ. Storage media and temperature maintain normal anatomy of cadaveric human skin for transplantation to full-thickness skin wounds. J. Burn Care \& Rehab. 2001; 22(6): 393-96. 
46. Sheridan R, Tompkins R. Skin substitutes in burns. Burns 1999; 25: 97103.

47. Van Baare J, Ligtvoet EEJ, Middelkoop E. Microbiological evaluation of glycerolized cadaver donor skin. Transplantation 1998; 65: 966-70.

48. Pigossi N. Implantação de dura-mater homógena conservada em glicerina [tese]. São Paulo: Faculdade de Medicina, Universidade de São Paulo; 1964.

49. Basile AR. A comparative study of glycerinized and lyophilized porcine skin in dressings for third-degree burns. Plast Reconstr Surg. 1982; 69: 969-74.

50. Ross A, Kearney JN. The measurement of water activity in allogeneic skin grafts preserved using high concentration glycerol or propylene glycol. Cell Tissue Bank. 2004; 5(1): 37-44.

51. Richters CD, Hoekstra MJ, van Baare J, du Pont JS, Kamperdijk EWA. Morphology of glycerol-preserved human cadaver skin. Burns 1996; 22: 113-16.

52. Hettich R, Ghofrani A, Hafemann B. The immunogenicity of glycerol preserved donor skin. Burns 1994; 20: S71.

53. Van Baare J, Buitenwerf J, Hoekstra MJ, Du Pont JS. Virucidal effect of glycerol as used in donor skin preservation. Burns 1994; 20: S77-S80.

54. Marshall L, Ghosh MM, Boyce SG, Macneil S, Freedlander E, Kudesia G. Effect of glycerol on intracellular virus survival: implications for the clinical use of glycerol-preserved cadaver skin. Burns 1995; 21: 356-61. 
55. Van Baare J, Cameron PU, Vardaxis N, Pagnon J, Reece J, Middelkoop $E$ et al. Comparison of glycerol preservation with cryopreservation methods on HIV-1 activation. J Burn Care Rehabil. 1998; 19: 494-500.

56. Cameron PU, Pagnon JC, Van Baare J, Reece JC, Vardaxis NJ, Crowe SM. Efficacy and kinetics of glycerol inactivation of HIV-1 in split skin grafts. J Med Virol. 2000; 60: 182-88.

57. Clarke JA. HIV transmission and skin grafts. Lancet 1987; 1: 983.

58. Eastlund T. Infectious disease transmission through cell, tissue and organ transplantation: reducing the risk through donor selection. Cell Transplantation 1995; 4(5): 455-77.

59. Simonds RJ, Holmberg SD, Hurwitz RL et al. Transmission of human immunodeficiency virus type I form a seronegative organ and tissue donor. N Engl J Med. 1992; 326: 726.

60. Kealey GP, Aguiar J, Lewis RW, Rosenquist MD, Strauss RG, Bale JF Jr. Cadaver skin allografts and transmission of human cytomegalovirus to burn patients. J Am Coll Surg. 1996; 182: 201-5.

61. Kobayashi H, Kobayashi M, McCauley RL, Herndon DN, Pollard RB, Suzuki F. Cadaveric skin allograft-associated cytomegalovirus transmission in a mouse model of thermal injury. Clin Immunol. 1999; 92(2): 181-7.

62. Kagan RJ, Naraqi S, Matsuda T, Jonasson OM. Herpes simplex virus and cytomegalovirus infections in burned patients. J Trauma 1985; 25(1): 40-5.

63. Bale JF Jr, Kealey GP, Massanari RM, Strauss RG. The epidemiology of cytomegalovirus infection among patients with burns. Infect Control Hosp Epidemiol. 1990; 11(1): 17-22. 
64. Herndon DN, Rose JK. Cadaver skin allograft and the transmission of human cytomegalovirus in burn patients: benefits clearly outweigh risks. J Am Coll Surg. 1996; 182(3): 263-4.

65. Clerici M, Berzofsky JA, Shearer GM et al. HIV-1 from a seronegative transplant donor. N Engl J Med. 1992; 326: 564.

66. Rutan RL, Bjarnason $\mathrm{DL}$, Desai $\mathrm{MH}$ et al. Incidence of HIV seroconversion in paediatric burn patients. Burns 1992; 18: 216.

67. Vloemans AFPM, Schreinemachers MCJM, Middelkoop E, Kreis RW. The use of glycerol-preserved allografts in the Beverwijk Burn Centre: a retrospective study. Burns 2002; 28: S2-9.

68. Dhennin $\mathrm{CH}$, Desbois I, Yassine A, Benissad H, Lignee J. Utilisation of glycerolised skin allografts in severe burns. Burns 2002; 28: S21-5.

69. Kreis RW, Vloemans AFPM, Hoekstra MJ, Mackie DP, Hermans R. The use of non-viable glycerol-preserved cadaver skin combined with widely expanded autografts in the treatment of extensive third degree burns. $J$ Trauma 1989; 29(1): 51-4.

70. Richters CD, Hoekstra MJ, van Baare J, du Pont JS, Kamperdijk EWA. Immunogenicity of glycerol-preserved human cadaver skin in vitro. $J$ Burn Care Rehabil. 1997; 18: 228-233.

71. Mackie DP. Postal survey on the use of glycerol-preserved allografts in clinical practice. Burns 2002; 28 (Suppl 1): 40-4.

72. Brans TA, Hoekstra MJ, Vloemans AF, Kreis RW. Long-term results of treatment of scalds in children with glycerol-preserved allografts. Burns 1994; 20 (Suppl 1): S10-S13. 
73. Peeters R, De Caluwe D, Neetens C, Hubens A. Use of glycerolized cadaver skin for the treatment of scalds in children. Burns 1994; 20 (Suppl 1): S32-S33.

74. Vloemans AF, Middelkoop E, Kreis RW. A historical appraisal of the use of cryopreserved and glycerol-preserved allograft skin in the treatment of partial thickness burns. Burns 2002; 28 (Suppl 1): S16-20.

75. Castagnoli C, Stella M, Magliacani G, Alasia ST, Richiardi P. Anomalous expression of HLA class II molecules on keratinocytes and fibroblasts in hypertrophic scars consequent to thermal injury. Clin Exp Immunol. 1990; 82(2): 350-4.

76. Pruitt BA Jr, Levine NS. Characteristics and uses of biologic dressings and skin substitutes. Arch Surgery 1984; 119: 312-22.

77. Stedman's medical dictionary. 27 a ed. Philadelphia, PA: Lippincott Williams \& Wilkins; 2000.

78. Furnas DW. Composite autologous-allogeneic skin replacement: development and clinical application - discussion. Plast Reconstruct Surg. 1987; 80: 636-37.

79. Houaiss A. Dicionário Houaiss da Língua Portuguesa. Rio de Janeiro: Objetiva; 2001.

80. Wainwright DJ. Use of an acellular allograft dermal matrix (Alloderm) in the management of full-thickness burns. Burns 1995; 21: 243-8.

81. Wainwright D, Madden M, Luterman A, Hunt J, Monafo W, Heimbach D, Kagan R, Sittig K, Dimick A, Herndon D. Clinical evaluation of an acellular allograft dermal matrix in full-thickness burns. J Burn Care Rehabil. 1996; 17(2): 124-36. 
82. Lattari V, Jones LM, Varcelotti JR, Latenser BA, Sherman HF, Barrette RR. The use of a permanent dermal allograft in full-thickness burns of the hand and foot: a report of three cases. J Burn Care Rehabil. 1997; 18: 147.

83. Munster AM, Smith-Meek M, Shalom A. Acellular allograft dermal matrix: immediate or delayed epidermal coverage? Burns 2001; 27(2): 150-3.

84. Callcut RA, Schurr MJ, Sloan M, Faucher LD. Clinical experience with Alloderm: a one-staged composite dermal/epidermal replacement utilizing processed cadaver dermis and thin autografts. Burns 2006; 32(5): 583-8.

85. Steinmuller D. Passenger leucocytes and the immunogenicity of skins allografts. J Invest Dermatol. 1980; 75: 107.

86. Perry LL, Williams IR, Shelby J. Anti-la immunotherapy in transplantantion : inhibition of skin and heart transplant rejection by induction of donor-specific immunosupression. Transplant Proc. 1986; 18: 910 .

87. Roitt IM, Delves PJ. Transplantation. In Roitt's Essential Immunology. 10a ed. Malden, Massachussetts, USA: Blackwell; 2001. p.374-395.

88. Foster CA, Holbrook, KA, Farr AG. Ontogeny of Langerhans cells in human embryonic and fetal skin: expression of HLA-DR and OKT-6 determinants. J Invest Dermatol. 1986; 86: 240.

89. Junqueira LC, Carneiro J. Histologia básica. $9^{a}$ ed. Rio de Janeiro: Guanabara; 2001. Cap. Pele e anexos.

90. Umetsu D, Katzen D, Jabara H, Geha R. Antigen presentation by human dermal fibroblasts : activity of resting T-lymphocytes. J Immunol. 1986; 136: 440-46. 
91. Wolff K, Schellander FG. Enzyme-histochemical studies on the healing process of split skin grafts. II. 5-Nucleotidase, adenosinetriphosphatase, acid and alkaline phosphatase in autografts. J Invest Dermatol. 1966; 46(2): 205-12 apud Cuono CB 1986, p. 1123.

92. Price RD, Das-Gupta VB, Harris PA, Leigh IM, Navsaria HA. The role of allogenic fibroblasts in an acute wound healing model. Plast Reconstr Surg. $2004 ; 113(6)$ : 1719-29.

93. MacNeil S. What role does the extracellular matrix serve in skin grafting and wound healing? Burns 1994; 20 Suppl 1: S67-70.

94. Livesey SA, Herndon DN, Hollyoak MA, Atkinson YH, Nag A. Transplanted acellular allograft dermal matrix: potential as a template for the reconstruction of viable dermis. Transplantation 1995; 60(1): 1-9.

95. Hoffman D, Sibley R, Korman J et al. Light microscopic and immunohistochemical features in serial biopsies of epidermal versus dermal allografts. Ann Plast Surg. 1994; 33(3): 295.

96. Wu J, Barisoni D, Armato U. An investigation into the mechanisms by which human dermis does not significantly contribute to the rejection of allo-skin grafts. Burns 1995; 21 (1): 11.

97. Mathes DW, Randolph MA, Solari MG, Nazzal JA, Nielsen GP, Arn JS, Sachs DH, Lee WPA. Split tolerance to a composite tissue allograft in a swine model. Transplantation 2003; 75(1): 25-31.

98. Lomas RJ, Cruse-Sawyer JE, Simpson C, Ingham E, Bojar R, Kearney JN. Assessment of the biological properties of human split skin allografts disinfected with peracetic acid and preserved in glycerol. Burns 2003; 29(6): 515-25. 